\title{
WestVirginiaUniversity
}

THE RESEARCH REPOSITORY @ WVU

Graduate Theses, Dissertations, and Problem Reports

1953

\section{Berkeley County in World War II}

Patricia W. Alger

West Virginia University

Follow this and additional works at: https://researchrepository.wvu.edu/etd

Part of the United States History Commons

\section{Recommended Citation}

Alger, Patricia W., "Berkeley County in World War II" (1953). Graduate Theses, Dissertations, and Problem Reports. 4023.

https://researchrepository.wvu.edu/etd/4023

This Thesis is protected by copyright and/or related rights. It has been brought to you by the The Research Repository @ WVU with permission from the rights-holder(s). You are free to use this Thesis in any way that is permitted by the copyright and related rights legislation that applies to your use. For other uses you must obtain permission from the rights-holder(s) directly, unless additional rights are indicated by a Creative Commons license in the record and/ or on the work itself. This Thesis has been accepted for inclusion in WVU Graduate Theses, Dissertations, and Problem Reports collection by an authorized administrator of The Research Repository @ WVU. For more information, please contact researchrepository@mail.wvu.edu. 


\section{Thesis}

Submitted in Partial Bulfillment of the Requirements for the Degree of Master of Arts in the Faculty of the Graduate School of West Virginia University

Patricia $W^{0} 0^{0}$ Alger, B. A. Hood collëge, 1945

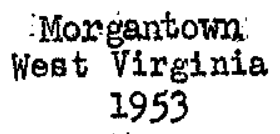


The author wishes to express her appreciation to Professor

Festua P. Summers whose guidance and criticism vere inspirational; to her father for his interest and helpful suggestions; to the many people who contributed information and in other ways showed an active intereat In this atudy; to her three chilaren for their cooperation auring the pest winter's regime of the seven o'clock bedtime; and finally to her husband who assisted in countless ways from lightening household dutles to arranging interviews--81ncere thanks.

\section{P.W.A.}

Martinsburg, W. Va. March, 1953 
TABLTI OF CONTEMTS

Page

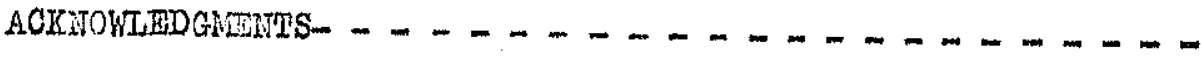

OHAFTER

I. MILITARY $\ldots \ldots \ldots \ldots$

Selective Service _ _ . . . . . . . . . 1

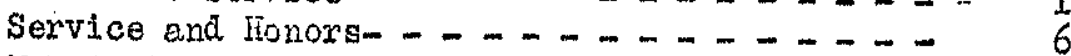

War Training Service Unit . . . . . . . . 11

II. HOME BRONT - . . . . . . . . . . . 15

Civilian Defense - - . . . . . . . 15

Red Oross - ... . . . . . . . . . . 28

Fducationel. System - $\ldots \ldots \ldots \ldots$

State Guard - . - . . . . . . . 38

III. INDUSTRY $\ldots \ldots \ldots \ldots$

Agriculture - . - . . . . . . . . 48

Beltimore and Ohio Rallroad _. . . . . . 5 .

Limestone Industry _. . . . . . . . . 60

Textiles - . . . . . . . . . . . 61

Fruit Products ................. 64

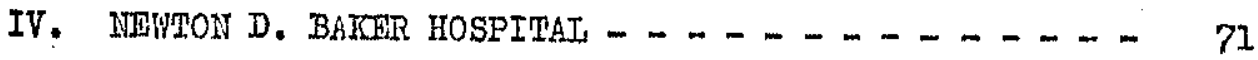

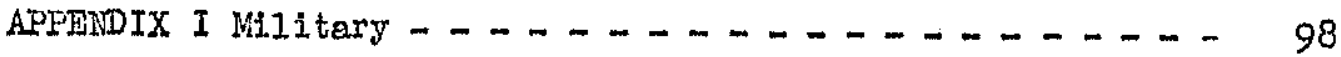

APPEMIX II Otvilian Defense - . . . . . . . . . 114

APFEMDIX III Map of Berkeley County _ _ _ _ _ _ . _ 121

BIBLIOCRAPHY - . . . . . . . . . . . . . 123

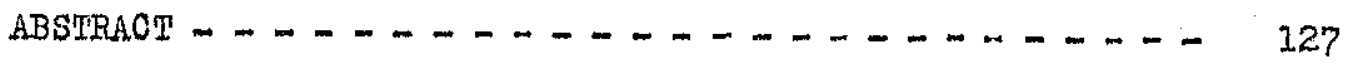

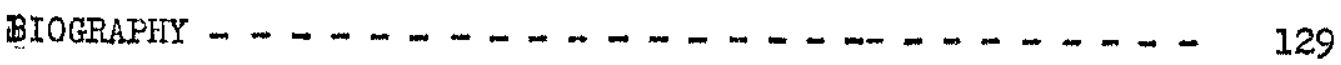

11

25420 
CHAPMER I

MIIITARY

\section{Selective Service}

In order to secure men for the armed forces effictently and equitably without disrupting the economic and soclal life of the nation, the Selectivo Service System was created by the federal government. The Selective Service Act which went into effect February 16, 1940 , provided that the governor of every state should appoint a local selective service board for each thirty thousand population, as well as an appeal board for each seventy thousand population. Medical examiners, medical and registrants' advisory boards and local board appeal agents should also be appointed through the governor's office.l

The function of each local board was to register the malo population between the specified age limits, clessify 1t, select those men fitted for military service, and deliver them for induction at the eppointed times. 2

The Berkeley County Selective Service Board. was established July 26, 1940. Its organization was carried out by Mr. Herold 0. Keedy, of Martinsburg, Clerk of the County Court, acting upon orders received from Governor Homer A. Holt. Mr. Keedy enlisted the ald of the election registrars, and with a few additional volunteers, prepared for the first registration. This was held on october 16, 1940, accounting for 3,600 men between the ages of twenty-one and thirty-six. ${ }^{3}$ 
During this month also, the governor appointed three Berkeley County men to compose the local selective service board. The board met and organized on October 28 , electing a cheirman, secretary and clerk. It served unt1l July 15, 1941, when, due to pressure of business and 11.1ness, the members resigned and a new board was appointed. The new board, with the Patterson Building in Martinsburg as its permam nent headquarters, contlnued to serve throughout the wer years, rendering efflcient sorvice in the best interests of the registrent, his family and his employer. 4

To assist registranta in the completion of their selective gervice questionnaire, the governor in october appointed an advisory board with the Honorable Decatur H. Rodgers, a judge of the circult court, as chairman. This board, composed of prominent local attorneys, was enlarged during later registrations.5

The second registration was held July 1 , 194.1, by the board with the asgistance of the office force and volunteerg. At this time there were 175 registrants, laxgely those who had reached the age of twentyone since the previous october. Other registrations were cerried out in a similar manner, 6 , with one major change. Beginning with the thira registration, February 16, 1942, which extended the age limit to fortyfive and included a total of 1736 men, centers were established throughout the county for the convenience of the registrents. These centers were manned by cttizen volunteers who had been trained by the clark of the board. The steff assistence section of the local Red Cross chapter aided greatly in these activities, as did ofvic, patriotic and other organizations whenever thetr servioes were needed.? 
On Apri1 27, 1942, the fourth registration accounted for 2,400 men between the ages of forty-five and sixty-five. The fifth, on June 30 , 1942, registered 569; at this time the dreft gge was lowered to elghteen. The sixth registration began December 11, 1942, and. was carried on as a continuous process, registering men as they became of age. 8

Reglstrants were classified according to the regulations handed down by national headquarters of the selective service. Registrants "sound of body and mind" were considered for class I-A unless their removal caused a definite hardahip as, for example, from a farm, or would hinder the production of some material vitaliy needed in the war effort. If such conditions were the case, however, and there was no posatbility of being replaced by an older man, the registrant was considered for deferment for a six-month perlod. 9

As the various deferment cases came before the board it gradualiy established a policy for future cases of similar types. In cases of Industrlal deferments it was the consensus of opinion of the board members that industry generally could function efficiently with men too old or physically unfit for military service. Most industries cooperated fully; a few, however, were a little slow to fall in Iine with the polloy and Insiated at first upon keeping every employee. The farm labor board worked in cooperation with the draft board, passing on applications for farm deferment before they would be considered by the latter board, and eliminating those which were not vital. The precedent established was that the farm mat supply products essential to the war effort to the extent of $\$ 2500$ a year for each employee. Orcherd workers were rarely considered for deforment since the nature of their work made 1t possible in most cases to secure replacements. The public, as a whole, seemed to be in accord with these regulations. 10 
As to other types of deferments, the dependency allowance was enough to provide for most dependents; therefore a dependency deferment was not granted except in casos of extreme hardahip wherein a men's presence was needed in the preservation of Ife. These were classifled $3-D$, and a total of three such registrants passed through the local board. There were few conscientious objectors, only one beinf actually classified 4-B, and he became 4-F upon physical examination. The three who came under the classification of delinquent were turned over to the alstrict attorney and indicted by the United States Oourt. One of these was sentenced to a federal penitentiary; on being inducted Into the service one of the other two falled to pass the physical, and the third was later kiljed in battle. ${ }^{11}$

The order number system was used by the boerd to select 1-A registrants for screening. A group of examining physicians was chosen by the board to administer the examination. The physicten chosen as chairman of the examining board appointed each assistant to a special task, such as checking physical defects, eyes, noge, heart, and so on, which constituted one phase of the examination. Systematic organization of this nature permitted a thorough examination of large groups with a minimum of work for each station. The Berkeley County Health Department and the Red Cross supplied technlclans as assistants for the examining doctors. These tests were simliar to those given at induction centers but were not quite as thorough. The absence of both an X-ray machine and a psychoanalyst shortened the local process by two stations. Other systems of examining had been tried previously but were found less efficient. 12

The final phase of selective service work was that of remployment and readjustment. The first reemployment committeeman selected was 
Mr. W. 2N. MoBride, who served from september 20, 1941, to september 25, 1945, when he was succeeded by Mr. G. C. MoKown. Through the efforts of this committee a number of ex-service men have been reatored. to their former positions and some have had new positions secured for them. One example of the comnittee is effectiveness was the case of a veteran who was roloased from his job in a local factory shortly after being rehired upon his return from the service. He presented his case to the reemployment committee, which in turn contacted the plant superintendent for further investigation. The veteran and a company representative were brought before the committee for a review of the case and the comnittee, after the hearing, recommended that the veteran be given another chance. Notified of this recision, the company contacted the veteren and reached an agreement with him whereby he was to return to work, receiving his regular wage for time lost in addition to a cosh payment proviaing he release any clalm ageinst the company. ${ }^{3}$ The average vetoran roturned with the expectation that the position which he had held before entering service would again be open to him. Most employers were very cooperative and often elevated their returning employees to a better position than before. There were a few difficulties in placing former service men since in many industries expansion had caused an Increase in the number of employees and rearranged the jobs. To this end the United States Imployment Service lent invaluable assistance. 14

In all phases of its work the locel board functioned smoothly and efficiently, meeting its varying monthly quotes from the time of the first call in November, 1940, to the present. Volunteors mode up a large part of severe.1 quotas; at least one was entirely volunteer. 15 
Service and Honors

The first known casualty from Berkeley County was Guy F. Powell, of Martingburg, a civil engineer in the Philippines, who was killed by enemy action on Decomber 29, 1941, at Fort Mi11s, near Corregidor. 6 John N. Richerds, also of Mertinsburg, had been severely wounded in the attack on Pearl Harbor, December 7.17

Sergeant Gilbert R. Jones, of Martinsburg, served as gunner on a B-24 Iiberetor bomber with the 15th Army Alr Force in Italy. "Bor meritorius achievement in aerial flight while participating in sustained operational activities against the eneny, "Sergeant Jones was awarded the Alr Medal. 18

Captain John N. Kilmer, a Martinsburg physician, distinguished himself in the fighting around Aprilia and Campoleone during the Italin campaign. He received the Silver Star Medal with the oltation which follows:

Captain KIlmer's battalion ouffered severe casualties when 1ts position was heavily shelled. He moved through the battalion area while flring was in progress, supervising first ald for alli wounded and directing evacuation. His efforts were an ingpiration to the troops of the battalion and undoubtedly were reaponsible for saving many Iives. Captain XIlmer's courage and devotion to duty reflect high credit on the Armed Forces. 19

For gallantry in action in the air war over Italy, Lleutenant

Joseph W. Haas, a pilot with the Twolfth Air Force, was awarded the Distinguished Wying Cross. The citation reads in part:

- . for repeatediy strafing a concentration of enemy transportation when his aircraft was bady damaged by enemy fire, and destroying four large motor transports and damaging eleven other vehicles. 
The flight group to which Lieutenent Haas was attached was part of an Anerican unit supporting the British Bighth Arny in Italy. It had given an inpressive account of 1 tself in the Iiblan, Munisian, Sicilion, Itallan and French cempaigns. 20

Ifeutenant Harry H. Mitchell, Jr., bomberdier on the flying fortress Sunrige Serenader, was awarded the Distingulshed Flying Oross for "extraordinary echlevement" and for his "courage, coolness and sk11." during the many bombing attacks in which be participated over German industrial centers and military targets in France. Iieutenant Mitchell had previougly been awarded the Air Medal with three oak-leaf olugterg. 21

The Bronze Star Medal was presented to Private First Cless Iloyd H. Runkles of the 394th Infantry for herolc achlevement in action on the German front, March 3, 1945. Runkles made his way with his machine gum through the hall of enemy fire which pinned down his conpany, until he reached a position from which he could sweep his fire across the enemy emplacements. He inflicted heavy losses of both men and equipment. 22

From the war in the Paciflo came other reports of gallantry in action. Iieutenant Frank 0 . Thomas, Jr., a Marine Corps fighter pilot, flow forty-one combat missions over Japanese territory. On one mission over Rabaul his plane was shot down by Japanese anti-alrcraft fire. Thomas balled out over the ocean, suffered a broken leg, and was finaliy rescued by amphibious plane. He wos awarded the Navy Oross with the following citation:

On January 9, while escorting bombers over the heavily fortified Rabeul, New Britain, area, he attecked and shot down two enemy fighters, probably destroyed two more and damaged a fifth. On January 27 , while again protecting bombers over Rabaul, he repel.jed an attack by a large number of Japanese fighters, destroying three of the intercepting aircraft. His courageous conduct and superior 
airmanship against hazerdous odds contributed materially to the success of each misston and was in keeping with the highest treditions of the United States $\mathrm{N}_{4} \mathrm{vy}$ ? 3

Three local Marines, Lieutenant Harold B. Thurston of Pikeside, and Private First Class William A. Woods and Private Roy Knadior, both of Mertinsburg, and all of the Fifth Division, participated in the famous landing on Iwo $\mathrm{J} 1 \mathrm{rog}, 24$

The opening of the sea war in December, 1941, found Iieutenant Commander Charles $N$. G. Hendrix, of Martinsburg, who had been graduated. from the navel academy at Annapolis in 1939, alresdy on submarlne duty In the Philippines. During the early months of the war, life on a submarlae seemed to be a series of narrow escapes. On one occasion, finding his path blocked by a convoy of Japanese warships, Hendrix with his sub sailed directly under the convoy to safety. On his first tour of submerine duty he had taken part in the sinking of a 14,000-ton enemy tanker and a heavily loaded Japanese troop transport. Later, he became an executive officer on the femous submarine, Sturgeon, which sank a large Japanese destroyor, captured two Japanese survitors near Wake Islend, and rescued three Americen flyers who had been shot down near Marcug. Hendrix was twice awarded the Sliver Star Medal and also received the submarine combat insignia with three stars. 25

One of the first county men to be teken prisoner by the Japanese was Corporal Alfred Dorsey Collins, Jr., who was reported missing in action in January, 1942. Except for the two postcards which he was permitted to send, Corporal oollingt family had no word from him during the remainder of the war. After $V-J$ Day they recelved a letter from him stating that he was well, though having lost considerable weight, and expected to be home soon. 26 
Gunner's Mate W. B. Taylor and Pharmacist's Mate W. C. Boutyard, both of Martinsburg, were members of SAOO, the Sino-Amerloan Neval Organtzation which served as weather observers, intelligence agents and guerillas behind the Japanese lines. In order to carry on their work, many of the Amerlcang in this group learned to disgulse themselves expertly as Chinese. 2 ?

Several Berkeley Countlans, among them Paul B. Martin and the brothers Brank $\mathrm{S}$, and Alien R. Bmoert, Jr., volunteered for duty with the American Field Service. Members of this unit, which helped supply ambulance drivers for the British Army, furnished their own uniforms and equipment and recelved as pay twenty doliars a month. 28 The brothers, Frank and "Buzz," lost contact with each other upon beine assigned to two different units attached to the British Eighth Army in Itely. One night while driving down a bottle-scarred Italian road, Brank became annoyed by the blinding lights of an approaching vehicle, stopped and got out of his ambulance to wait for the oncoming driver. The argument which ensued was cut short with leughter as one brother recognized the other, and a happy reunion followed. 28

One of the highest ranking naval officers in Berkeley County and the surrounding territory was Commodore Thomas D. VanMetre of Martineburg, en Annopolis graduate, who commanded a fleot of submarines during Forld War I. After the outbreak of World War II he was made Doputy InspectorGeneral for the United. States Navy, with headquarterg at the Pentagon Bullding in Washington. 29

Corporal Reno F. Markle, of Bunker Hill, who was reported mlsaing In action in France but later returned safely, was one of five brothers In service from the county. 30 sour sons of $\mathrm{Mr}$. and Mrs. J. I. Mongan, 
of Martinsburg, wore called to duty, ${ }^{31}$ as were the four sons of Mr. and Mra. Robert Stewart, only three of whom returned. There were many more than these; quite a few service flags which hung in the front windows of homes in the county contained at least several stars. It would be impossible in a work of this type to list the deeds of brevery performed by our men in service, even if all were known. Records are sketohy; cltations are often stiff, formalized wordings concealing depths of heroism known only to the few men involved. And countless other acts were passed by unnoticed in a time when the herolc was the commonplece. The incidents cited here were intended only to serve as a reminder that when our woy of Iffe was being tried on the battlefronts of the world, men from the farms and towns of Berkeley Oounty were giving to their uttermost.

Celebrations on V-W (Victory in Furope) Day, May 8, 1945, were quiet, most of them in the form of dedications to a task not yet completed. 32 On V-J Day, the following september 2, hovever, mill whistles blew, girens sounded and people rejolced as the tensions of the past four yerra fell. from them. 33

The general rejolcing here, as everywhere, was soon tempered by the knowledge that though peace had come, the after-effects of war were inescapable. One of these effects was pointed out graphicaliy to the people of the county by one of 1 ts native sons, Sergeant Garnett $W$. Shipley of Martinsburg, who lost his right arm and his left leg in Normandy. Sergeant Shipley, from his bed in MoGuire General. Hospital, Rlchmond, wrote an editorial for the post newspaper which was later reprinted in the Martinsburg News. Said he: 
The war was ended for those of us who came through reasonebly sound and whole-and for those of us who died before returning:

But to those of ua who only died in part-who loft behind a part of our 4 physical beings as hostages to Mars--VICTORY is yet to come.

Berkeley County was also well represented by its women in service. Virginia Butts Whitacre was the first to be aworn into the WAAC, while Louise Henshaw was the Plrst to join the non-commissioned branch of the WAVHS. 35 Nurses from the two Martinsburg hospltals went into both branches of the service. Three Kings Daughters Hospltal graduates, Peger Grove, Edne Richards and Catherine Welty, chose to be sworn into the Navy Murse Corps by a former hospltel staff member, LieutenantCommander Marvin Porterfield, when the latter was home on leave in Auguat, 1942.36

Names of other Berkeley County women in service are Iisted in the appendix. The statistics, as nearly as can be gathered, show that the county furnished forty-four WAOs, twenty-four WAVES, three Marines, eight Army Nursos and eight Navy Nurses.37

\section{War Mraining Servico Unit}

During the first year of the war the militery found itself handicapped by an acute shortage of aircraft personnel. To alleviate this condition, colleges and universities throughout the country were urged to undertake, in connection with the Civil Aeronautics Authority, civilian pilot training programs for army and navy air cadets. In response to the call Southeastern University of Washington, D, O., sponsored a school which was opened in Mart1nsburg on September 15, 1942, under the direction of didward D. Melgs, flight training commander, and Captain Fiagar M. Sites, in charge of the student's military training. $B$ 
The program became offlcialiy known as the $W_{a}$ tralning service. The first class of thirty-two student-pilots received their wings in graduation exercises on Jenuary 9, 1943.39 The school remained open until late the following fall, when the army and navy atr corps were considered sufficiently staffed and the nationwide program was brought to a close. 40 Diuring the year of 1 ts operation, over five hundred reserve army and navy air codets were given the oight-woeks 1 courge which consisted of four units: primary and secondery flight trafining, and primary and secondery cross country. 41

Hach course averaged forty hours of flyling. One gilder unit was offered; In addition the men were taught aero-dynamics, aircraft motors, meterorology, mathematios, physics, alrcraft ldentification, chemlcel werfere and basic military solence. A large percentage were afterwards commissioned as p1lots in the army and navy air corps.42

Equipment and use of the twenty to thirty planes stationed at Shepherd Field, located about three miles south of Martinsburg, were arranged for by Southeastern University and financed by the War Department. As quarters for the men, Southeastern officlals rented the $W$. $n$. Wurzburg house on West King Strest and, nearby on Tennessee Avenue, the vacant home of Dr. William J. Haltom, who was then on active duty with the army medicel corps. The DeHaven house on West King Street served as mess hall. 43 Most training was given at Shepherd Flying Field; however, because facilities at the local atrport were limited, school officials arranged to transport some flight classes to the airport at Winchoster, Virginia. The Martinsburg armory was used for some instriotion and for drill in bad weather. 44

The school was rated highly at inspections. Its work and standing were given special recognition by the Navy and War Departments. 45 
FOOTNOTES

CHAPTER I

1 West Vixginia Blue Book, 1946, p. 302 .

2 Ibid.

3 History, Iocel Board, Selective Service, Martinsburg, Berkeley Countx, Weat VIrginia, by F. M. Sites, Clerk. Hereaftar oited as History:

4 Ibld.

5 Ibla. Complete list of members of boards in appendix.

6 The Martinsburs Journal, December 24, 1941; January 5, 1942.

7 sites, History.

8 Ib1d.; Martinsburg News, December 24, 1942.

9 Sites, History.

10 Ibld.

11 Ibia.

12 Ib1a.; The Martingburg Journal. Jebruary 3 and 4, 1942 .

13 sites, History.

14 Ibia.

15 West Virginia Blue Book, 1946, p. 303; Martingburg News, October 9, December 4, 1942; Jebruary 26, July 9, November 5, 1943.

16 the Martinsburg Journal, January 31, 1942.

17 Martinoburg News, May 15, 1942.

18 Ibld., November 17, 1944.

19 Ibia.. September 22, 1944.

20 Ibla., November 10, 1944.

21 Ib1a., October 20, 1944.

22 Ib1d., June 29, 1945.

23 Ib1d., 0ctober 20, 1944. 
24 Ib1d., May 18, 1945.

25 Ibid., October 26, 1945.

26 Ibla. September 14, 1945.

27 Ib1d., September 28, 1945.

28 Ib1d., Decembor 1, 1944.

29 Interview with Mrs. John G. Byrer, niece of Commodore VanMetre, January $5,1953$.

30 Martingburg News, February 16, 1945.

31. Iold.. July 23, 1943.

32 Ibia., May 11, 1945.

33 Ib1a., September 7, 1945.

34 Ib1a.., September 21, 1945.

35 Ibia., October 9, 1942.

36 Ibid., August 14, 1942.

37 West Virginia Selective Service Headquarters, Charleston; supplement ed by DIscharge Records, Berkeley Dointy Olerk's Off1ce, Martinsburg; and Martinsbure News files.

38 Interview with Gaptain Sites; Martingburg Newg, January 8 and 22, 1943.

39 Washington offictals appearing on the program were: Oharles I. Stanton, Administrator of CAA; J. J. Morris, Director of War Training Service of CAA; W. S. Stewart, Assis tant Director; Charles Plank, OAA Puble1 1 ty Director; and Dr. James A. Bell, President of Southeastern University. Martinsburg News, January 8, 1943.

40 Ib1d. . July 23, 1943.

41 Ibid., September 11, 1942; May 28, 1943.

42 Interview with Captain sites.

43 Martinsburg Neus, August 8 and October 2, 1942.

44 Ibid., October 2, 1942, and interviow with Captain sites.

45 Ibia. 


\title{
OHAPTHR II
}

HOME SRONT

\begin{abstract}
"The unhappy consequences of our past, patient unwisdom and inaction, crowd upon us. Dlscussions of such moot questions are idle. Action alone cures. Academic debates axe being settled by the stern volces of bombers in the air, by the mighty battle tones on land and sea. Today, one sentiment must prevail-mo the Front? Not alone is that front at pearl Harbor, Midway, Wake Island, Guam, Manila, and in a thousand other spots crueliy important. That front may be at your door, your elbow. It may be within your business organization. It certalnly 1s wherever the life of any defender of our country is jeopardized by the cunning trickery and sebotege of seeming friends or secret enemies:1
\end{abstract}

\section{Civilian Defense}

Martinsburg is fifty eir miles from the nation's capital. Its proximity to Washington, as well as other industrial centers such as Baltimore and Higerstown, Maryland, placed Berkeley Oounty in the taog-fight' zonem-the area over whlch ldogmights' would occur between United Stetes and enerny planes in case of an attack on any of those cities. 2 There was also the posstbillty that enemy bombers bound for Washington might decide to rendesvous at a point behind the target, for instance over Harpex's Berry, in nelghboring Jefferson Oounty, where the Shenandoah River flows into the Potomac and forms with the Baltimore and Ohio Railroad a well-defined path to Washington. If the eneny 
should for some reason jettison his bombs, they might strike anywhere in the area.

Beaides 1ts stretegic location on the Potomac, Berkeley County is situated on two main arteries of transportation: the Beltimore and Ohlo Railroad, running east and west, passes through Martinsburg, as does U. S. Route Fileven, which nearly parallels the eastern seaboard and was chosen by military authorities as the nation's second line of defense. At the outset of the war Route mleven was widened and sufficiently strengthened to withstand the wear of heavy equipment. In caso of successful amphibious landings on the Atlantlc Coast, plans were to Install defense equipment 'parks' at intervals along the highway whlch would then become the front Ine of the nation. 3

In the same event of attack up on any of the nearby cities, the wounded and perhaps other evacuees vould be transported here as well as to other less densely populated areas. Olvilian Defense, Red Cross and State Guard officials kept this possibility in mind.

Carleton 0. Pierce, state executive director of civilien defense (Iater succeed by Carl. G. Bachmann) sent a letter In November, 1941, requestlng all West Virginia sheriffe, mayors and county courts to undertake the organization of local defense counclls and outlining the suggested procedure.4

A chairman and vicomairman must first be solected and charged with choosing the council, which should include representatives of the following phoses of communty life: protection, with all existing authorities within the county responsible for police and fire protection; utilities, such as commulcation, 11ght, power, transportation; oducations 
business and industry, agriculture, heal th and welfare, these divisione incorporating housing and subsiatenco, medical services, hospitals, Rei Cross and sanitation; information, including newspapers, radio and speakers; labor; veterans' and service orgentzations; women's activities; and fineliy defense bond and stamp sales. Names of council members should be sent in for certification by the governor, and, once installed, members should proceed to orgenize their work along committee Iines.5

A defenoe council had been set up in Berkeley Oounty late in 1940, w1th Fdgar H. Berxy, of Mertinsburg, as chairman. It met on numerous occasions, drew up a constitution, 6 discussed plans for the defense of the county and promoted defense bond sales and the aluminum drive. Not until after Pearl Harbor, however, was public interest aroused to the point where definite steps could be taken to put the plans 1nto operat1on.?

When, upon the outbreak of war, the seriousness of the situation became apparent, committees were appointed and the organization worked In close cooperation with stete and national civilian defense authorit1es. 8 A list of county personnel will be found in the appendix. A report of Philip J. Cochran, Supervisor of the Second District, in January, 1943, indicates that the people of the county and their leadors had taken an active interest and that the defense progrem during its first year had made excellent progreas?

Air Rald Warning Service. Martinsburg was divided into seven zones, corresponding to the seven wards. In the county the zones followed the Ilnes of the six magistertal districts. Hoading each major division was a zone warden who worked in conjunction with bis precinct wardens, sector wardens, and assistent sector wardens, of 
which there were from three to six in each sector. The total countywide organization included 1500 to 1800 men. Mr. G. William Ropp, chief air raid warden, in explaining the plan at the outset, sald that the "sector wardens are the key men in the setup and should be thoroughly femiliar with their block as to construction of bulldings and should also know the people living in the block as to their abilities to help in emergencies such as doctors, nurses, boy scouts and others. The success of the entire program depends...on how serlously the people take $1 t . .$. . It can be ruined by half-hearted interest or ridicule."10

Training courses for air rold wardens and their assistants began early in 1942, and included ten hours of first ald, three of fire fighting and five hours of general instruction. Upon completing his training each warden received on identification card and arm band with the air-precaution ingignia. Instructors of the first two classes were George Ropp and Monroe Janney 11 In April s1x local workers attended the alx ratd warden school. at Jackson's M111 and returned to stert classes of their own throughout the county. 12

The first "alert" was scheduled for 12:30 p.m. on December 17, 1941. Its purpose was to test the signals and let the poople become accustomed to them, in preparation for an actual blackout to come later. The siren atop Ryneal. Fire Hall on Beast Burke Street would sound a rising and feling signal for the "alert," and a single long blast fivo minutes later would gignify "all clear." At the appointed time, how ever, the alren was found to be defective and the test was postponod. I3

During the next fow weeks progress was interrupted by a shuffling of personnel in the executive committee. Berry resigned his post as county coordinator to accept a position in Richmond and was succeded by J. Howard Myerg, Sheriff of Berkeley County, who served unt11 
January, 1945, when he was called to Charleston to become clerk of the Hest Virginia State Senate.14 o. J. Orabill, of Martingburg, was named chalrman of the defense council, replacing W. S. Howard who also had. resigned.15 The interest and enthugiasm shown by these two men motivated the defense program throughout the war years.

The longmawalted blackout was finally held on Ihesdoy, May 19, 1942, announced in Martinsburg by all available sirens and factory whistles, and in the rural sections by auto horns, telephone calls and various other pre-arranged slgnals. The postoffice in Martingburg and the two plants engaged in war work did not particlpate, but 200 air raid wardens, 45 auxiliary police and a number of auxillery firemen were at their pos ts. The bleckout was reported suocessful and, even more importent, it great iy stimulated the publ1c interest in defense measures. 16

Other practice blackouts and alerts were held in the months that followed. On August 18, 1942, a county-wide blackout was held following civilian defense graduation exercises. Major J. P. Hesley, Iialson officer of the Iffth Corps Area, who had spoken at the graduation ceremonies, had high preise for officials and cltizen cooperation durIng the blackout, which he viewed from the air. Two major violations were reported: a service station with tourist oabins and a tavern, on opposite ends of Martinsburg, 17

On March 4, 1943, three Eastern Panhandle countles in collaboration with Virginle, Maryland, and Pennsylvanla, blacked out under the newlyInstituted system of four test signels. The first sounding of the sirens at $8: 27$ p.m. warned the beginning of the blackout. On the second signal, at 8:53, all moving vehicles were required to alm their lights. On the thira, at 9:12, traffic was stopped and all persons out of doors 
took cover. The second signal sounded again at $9: 22$ and traffic prom ceeded with din lights as before. The fourth, at 9:33, s1gnalled the all clear, ending the blackout. 18

The statewide blackout on June 29, 1943, lasted thirty-five minutes. Penalties for violations had by this time brought about more complete cooperation. 19 The blackout on August 31 of that yeer was a complete surprise, with no notice glven to any county offlciel. Director Myers reported public response greater than in any previous blackout; there were no violations and It wes generally agreed that this test "hit a new high in mobilization, "20

The training program for auxillary firemen was begun in January, 1942, under the direction of Fire Chief Roland Snyder and his assistants. Nearly all the pald members of both Ryneal and Westphal hose companies had been trained at fire schools in Morgantown and were qualified to act as instructors. Those who completed the course recelved identificotion cards, certificates and National Defense Firemen's Auxiliary armbands bearing the symbol of the Maltese Cross. Industries, theaters, hotels, hospital.s, churches and all other places where large groups of people might gather were asked to send representatives to the classes. 21 Both men and women responded to the call and at the end of a year the second district supervisor reported the flre-fighting system of the county "adequate in all respects."

Two drivers' Corps units were organized by women of Martinsburg, Pikeside and Fedgestillo. The group met orlginally at the county defense office to place their cars at the disposal of the visiting medical examining board, and then declded to form the corps to handle other of tuations which might come up. Personnel of the corps were those 
people willing to offer their cars and services whenever needed in the local defense effort. Members received the national drivers' corps insignia, a red steering wheel on white background, upon enrolling. Other drivers 1 units were provided under the Red Cross organization. 23 Training programs were also organized in the early monthe of the war for auxiliary police, emergency public utilitles, emergency public works, and a messenger corps was formed. On August 20, 1942, at Martinsburg High School, about 700 civilian defense workers particlpated in a review preceding graduation exercises at which 320 persons received certificates from the various schools of trainfine. 24 All. volunteer workers become eleglble for insurence benefits under the fre ingurance program of the national civilian defense organization. 25

In order to have at least several qualified civilian bomb experts In each county, five bomb reconnaissance schools were held throughout the state in the apring of 1943. Representatives from civilian defense organizations, state guard anits, state pollce and induatry in nolghborm ing countios in West Virginia, Maryland, and Virginia attended the Martinsburg school. 26 Sponsored by the War Department, the purpose of the UXB, or unexploded bomb, school was to teach civilian leaders what to do in case an unexploded bomb should land in the Vicinity. The army Instructor sent to conduct the classes had studied. first-hand the metlods practiced on home fronts in England. 27

The first in a geries of plant protection schools was also held. in Martingburg in March, 1943. Under this nationwide program all manufacturexs holding war moterlal contracts were requireo to organize protection programs and other plants were urged to do so, 28 
Since civ1lian defonse touched every phase of civilian life, its work necessarily overlapped that of most existing organizations. The school gystem and the Red Oross, for example, worked in close oooperation with It, as did the boy and girl scouts and the newspapers. Agriculture, with Its great problems of wartine food production, was turned over to the county agent and will be discussed in anothex chapter. A notable contribution to the county defenge effort was made by H. O. Collison, of Martinsburg, a retired Wegtern Union employee who volunteered hls servioes when civilian defense was first organized. $\mathrm{Mr}$. Oollison was given the duty of maintaining a smoothly functioning county office and this he did consolentiously until a stroke left him critically 111 in June, 1943. He had by this time bocome ellgible for the 3000-hour service ribbon, with which he was presented in a countywide ceremony that fall. 29

Salvage. While some phases of civilian defense recelved lass emphasis as the denger of Invasion lessened, others grew increasingly important. Among these was the salvage of metols, peper, fats and all other materials which might be reclalmed for use in the war effort.

The "Salvage for Victory" Committee, under the airection of Iou Oohen of Martinsburg, started a county-wide arive in June, 1942, to collect old rubber and scrap metal. A storage bin for the collectod rubber was built in the public square in Martingburg, 30 and five stations for depositing all types of scrap were set up at feed and supply stores throughout the county. The committee contacted farmers by telephone to urge that they cooperate in the drive. 31

In August, State Civilian Defense Director Oarl G. Bachmann assured county Ieaders of the use of State Road Commission trucks, while urging them to be active every minute and to call upon everyonell in this essential defense activity. 32 
A second drive with the slogan "Get in the Scrap I" was set for Sunday, October 4, 1942, with Harry Hamann of Martinsbure as drivo chalrman. Boy and Girl Scouts and air rald wardens made prelininary canvasses to determine the avallable amounts of materlal which, for this campaign, included scrap metal of all kinds, rubber, rope and burlap. The looal Amexican Iegion post offered a silver loving oup to the school whose students brought in the most signed promised of donations, and another cup for the classroom with the most pledges.33 pub1io and independently-owned trucks collected all day on October 4, and on subsequent Sundays. There was some objection to the sunday collections, but the committee had chosen the only day when most trucks were oveilable. 34

Oriswell's BIorista, of Martinsburg, added interest to the campaign by displaying in their shop window a collection of keys strung on a wire In the shape of a large V. The "keylection," which included several six-inch brass keys, some that were antique, and one to smell gold locket, grow as poople added their unusod keys to 1t. Whon it was turned over to the salvage committee at the close of the drive, the collection numbered close to 5000 keys. 35

Scrap collected by the salvage committee was sold to local junk dealers and the proceeds uged by the county defense organization to purchase equipment such as air rafd wardeng' helmets. By mid-December, 1942, the locel drives had netted $\$ 2229 .^{36}$ other organizations added to thelr treasuries in the same manner.

Whe third scrap drive was held in November, 1943, again headed by Harry Hamann, with each air rald warden in charge of canvassing 
hls sector. 37 other collections were made from time to time between drives, and monthly reports ware aent by the committee to the state headquarters at Charleston. 38 County quotas were handed down by state salvege officials, but these often went unfilled. 39 Nevertheless, Berkeley was the firat county in the state to recelve the War production Boara Salve.ge Pennant Award. 40

Tin cons were colleoted and flattened for shipment by shool children under the leadership of Mrs. John Redue, chairman of the $t$ in can rally, and Oaptain Melvin Jewett of the Salvation Arny. 41 Boy and girl scout troops throughout the county made reguler monthly collections of old newspapers, scrap paper, magazines and cardboerd, profits going toward the purchase of new uniforms. 42

War Finance. To promote the ale of war bond and stamps the War Savings Staff was set up in West Virginia in September, 1941. Similar committees were organtzed under the direction of the state staff in each of the counties. In July, 1943, the United States Treasury Department merged the War Savings Staffs of the states with the Victory Fund Committees, composed of the nation's bankers, to form the Har Hinance Conmittee, the central and permanent financing organization. A revamping of the state organization took place stmultaneously. The fiftyfive countieg were divided into eight regions with a chairman over each, and county committees were reorganized and enlarged accordingly. Berikeley Oounty was included in Region 7 with headquarters in Romney. 43

The poople of the county were quick to respond to the plea of the government to help finence the war. Sale of defense bonds and atamp boomed after the attack on Pearl Harbor. Whin a weok local 
postoffices and banks reported their sales tripled. 44 Before the end of December, the Martinsburg Postoffice had sold out of $\$ 25$ bonds. Sales continued, however, through the use of Washington-approved recelpts whlch would be exchanged by the purchasers for bonds when the new supply arrived. Bond and tamp ales totalod $\$ 86,518.70$ in December, more than three times the seles of a normal month. 45

Combined with the willingness of the people to buy was a cooperam tive movement among local businesses, schools and industries to expand the sales mediums and make bonds and stamps easily available to everyone: Individuals as well as groups; young and old. In Martinsburg, forty-one places besides the postoffice were handing stamp sales by the end of December. A plan had also been approved and started in several schools whereby puplis might save regularly by bringing their dimes and quarters to school and purchasing stamps to fill their albums. This savings plan was instantly successful, and after Ohristmas was extended to all the schools of the county. 46

To county leaders one fact was even more gratifying than the total sales in the early weeks of the campaign. The bonds most in demand were those of the smallest denomination (\$25). Th1s, together with the fect that December stamp sales were nearly twelve times that of lovember, showed that wage earners of average and even lower incomes had felt the necessity and were giving enthusiastic support to the war fund. 47

This enthusiasm was evidently sustained. Bond and stamp sales for the month of January, 1942, exceeded $\$ 100,000.48$ Salea in 1942 to Augrast 1, totaled $\$ 622,500$, and a quota of $\$ 120,000$ was set for the month of August. By this time every Martingburg industry of any size was cooperating in the payroll savings plan, begun in April, under which 
the worker automatically converted a portion of his earnings into bonds each paydoy. In the 10081 benks 200 man-hours per month were belng doneted without pay to the sales program. 49

At intervals throughout the war perlod, drives were held to emphasize and accelerate the bond purchase program. After the organization of the War Finance Committee, seven war loan ariveswere held netionally. County and state quotas were set for each drive after the first. Berkeley County sales progressed from $\$ 110,987$ in the first to $\$ 1,724,242$ in the seventh campaign, the latter exceeding its quota by 373.1 per cent. In one drive, the third, this county fell short of 1 ts quota, 50 but as the months went by, purchasing power increased. During the seven wer loans the people of the county invested a total of $\$ 6,688,399$ in their nation's future. This was an average oversubscription per drive of 121.3 per cent. 51

USO Servicements Center. The Martinsburg USO, of which the entire county was justly proud, was brought about largely through the efforts of one man, C. Gronville Smith, rooreation chairman of the Berkeley County Defense Counc1l. Throughout the spring of 1943, Mr. Smith and his committee made plans and solioited funds for the establishment of a center for the use of air cadets stationed in Martingburg, Newton $D$. Baker Hospltal patients and enlisted personnel, ond other members of the armed forces. 52

Work was begun early in July to remodel the Boyd Butlding in the public square, prewar location of the Dunn and Selbert Garage. Plans included the installation of a lunch oounter, dance floor, writing tables, ping-pong and pool tables, tollets, shover room and lounge, 
Blueprints and cost estimates vere furnished voluntarily by Willam A. Goff, architect engineer of Newton. D. Baker, and his staff. As the enthusiasm of the chairman spread throughout the community, donations began to pour in: cement, sand and gravel for the floor; venetian blinds and drapery material; a counter, tobles ano. chairs for the luncheonette; a colonial front doorway for the entrance; a gas range, a piano, and the $\$ 2000$ needed for construction and remodeling. 53 Additional funds for maintenknce were subscribed from time to time. Beginning in the fall, expenses were shared by the national United Services Organization. About $\$ 25,000$ in all. was spent on the center. 54

Ey the end of Augnst the center was ready for use, and shortiy thereafter became associated with the netional. Uso. J. T. Maddrey, of Ralelgh, North Carolina, a trained program director recommended by national headquarters, was employed by the local executive comnittee to manage and club under national regulations, Mrs. Paul Bennett and Mrs. John Redue, chalrmen of the senior and funior hostesses, respectively, had charge of registering persons interested in asgisting with social events. Miss Jane Ropp managed the snack bar. Upon the resignation of Maddrey in February, 1944, Mrs. Sallie Alles was appointed director. 55

Once organized, the USO functioned smoothly, expanding its services as Increasing numbers of patients were brought in to Newton D. Baker. Dances, with orchestras, held on Tuesday and Friday nighte, and the sundey afternoon music hours were well attended. Coffee was served free a.t all times and there was no charge for sunday eventng supper. Wednesday and Thursday nights were set aside for gervice men and women to make free recordings of their volces to send home ${ }^{56}$

A formel wedding was hold at the center on Thanksgiving eventing, 1943. One room was arrenged wth an oltar, candles and flowers, and 
at the dance following the ceremony wedding cake and refreshments were served by the Homen's Club of Martinsburg. The groom wes a sergeant on the hospitel steff; the bride, a civilian hospital employee.57

So popular did the USO become that by mid-winter of the first year It had outgrown 1ts quarters. In January, 1944, the executive commlte arrenged to expand the center by obtaining three rooms in an adjoining building to the rear. This made possible the opening in the spring of a terrece which overlooked tennis courts and horseshoe pits. 58

The Maxtinsburg USO received national publicity as an outstanding club. In 1945, of the 4000 in the nation, 1t was selected by the National Har Find and the USO Public Relations Department to be the subject of a publicity story appearing in magazines and newspapera throughout the country: 59 The center was closed June 30,1946 , having served, during its pook, an average of 25,000 men and women per month, 60

A USO for colored service personnel was also opened in Martinsburg through the efforts of the Smith committee. Located on West Race Street, the club held its formal opening on January 31,1945 , and we.s well attended until it clooged in June, 1946. Mrs. Bred I. Ramer was the club alrector. 61

\section{Red Cross}

The record of the Berkeley County Chapter of the American Red Cross has indeed been creditable. Ohartered in 1917, the chapter operated during World War I and carried on its routine health and welfare services in time of depression and aisaster in the peacetime interim. 62

As world-wide need for such services became greater in 1939, the chapter, in accord with national policy, prepared to expand. The call 
for relief to the overiun countries of Furope woe met during the summer of 1940 by an extended sewing program, in whlch garmenta were cut by the Perfection Garment Company, of Martinsbure, sowed by volunteers, usuolly in their homes, and assembled in the Red Cross room. A total of about 9000 women's and children's dresses and skirts, men's and boy's pajamas, baby loyettes, and 'toddlers' pecks' conslating of about thirty garments, resulted from this combined effort. 63

With the onset of World War II, new projects were launched. In cooperation with the Ferm Women's Olub the chepter begen to assemblo arny Iictt bags. T These utility begs, of whlch about 3600 were manufactured, contained some fifteen useful articles and were distributed to overseas-bound troops as they boarded the ships. 64

Materials for the clothing, kit bas and other such projects were purchased with the fifty million dollars which the federal government had aet aside for that purpose. From this fund also, the area Red Oross purchesed the yorn with which the local chepter carried out 1ts knitting program. The volunteer knftters produced a total of about 5000 garments, using two types of yarn. From the somcalled. Irefugee wool were made sweeterg, ceps, mufflers, scarves and similar articles for the needy peoplen of Burope, while the regulation militery wool went Into army and navy sweaters, helmets, scarves and cast covers. To facilitete the knitting program as well as to make sure that a minimum amount of yarn was wasted, the chapter made knitting instruction available to oll the women of the county. Various members also met with Girl Scouts, Junior Red Cross and other young volunteers, and no one started a sweater until sho had shown hor ability. As a result, the chopter has to its credit the fact that not one garment was returned. 
Bach wos inspected and then sent to one of the two professional dry cleaners who contributed blocking service. Recorde kept of the wool show that every bit was knitted up. 65

From June, 1943, to October, 1945, a surgical aressing room was in operation with sub-chairmen appointed for exch afternoon and evening. Surglcel. gauze was sent in, measured and inspected and about two and one-half milition dressings were folded for shipment overseas. Toward the end of the wor a waterproof wrepping was added in order that the bundles might be thrown overboard and pushed to their destination on the islends. 66

Some aurglcel aressings were also made for Newton D. Baker Generel Hospital, but more important thon these were the hundreds of thousands of necessary items which were sewed both before and after the opening of the ingtitution. The hospital furntshed unbleached muslin and a sample of each article, and Red Cross production workers went daily to the hospltal to do the sewing: 6 ?

The organization of these 800 to 1000 women who took part in the Red Cross wertime progrem was no small job. The chalrman, vice-chatrman, secretary and treasurer, in addition to all the corps chalrmen and a representative of each county district, a total of about thirty-gix with the new corps added during the war, met twice monthly: 68

It was through the corps that the greater part of the Red Cross contribution was made to the war effort. The first of these were the Nurses Aldes. After an eighty-hour course at the Kings Daughters Hospital these girls were assigned to the two Martinsburg hospltals and Newton D. Beiker, performing the routine duties which proved such valuable aid to the repidly diminlshing nursing steffs. Of the ninoty trained, six. went on the natlonal honor roll for over 2000 hours of service. 69 
The Canteen Corps consisted of over a hundred women who had passed the nationaliy preacribed forty-hour course. This group prepared lunches for the blood donors and in the case of several forest fires cerried. food back into the mountain to the firefighters. Oommittees working In shifts maintained thenty-foux-hour service at Newton D. Baker, while others met all incoming planes at the alrport with food for the pettent 8,70

To provide clerlcal assistance for all the chapter services a group of women with some knowledge of stenography volunteered. Two twentyfour-hour courses were held at Burke Street School in Martinsburg, from which sixty-four persons received certificates. Staff assistants wero thus available to the draft board when needed, to moblle unita, such as X-rey, and to the ration board. They regtitered all blood donors and kept complete Red Cross case records of service men. ${ }^{71}$

The Grey Ladies belonged to a group offichally known as the Hospltal and Recreation Oorps. By visiting and offering advice and counsel to the patients, shoppling for them occasionally, and bringing comfort in many small weys, these women proved their worth as morale builders. The corps as a whole provided outings and plonics for the men, among these being a trip to the White House, where they were received by President Truman. Since the work of this corps centered around Newton D. Baker, it was active, averaglng 275 hours a veek, unt11 the close of the hospltal in June, 1946.72

The Motor Corps was set up to provide tranaportation for members of all other corps, for example the canteen workers and Grey Ladies to and from the airport and hospltal, as well as bringing in blood aoners. About thirty-four recelved the training which included standard and advanced first aid and motor mechanics. The chapter was fortunate to 
have as tts offictal. vehicle a Buick which was lent for the duration by one of Martinsburg's leading cltizens. 73 This was turned back when the chapter later came into possession of a new Jord station wagon. There were no accidents of any kind. 74

The smallest corps was that of Arts and Skilla. Mode up of artists and professional people, it worked entirely at Newton D. Baker, helping In the occupational therapy department with pointing, ceramics, plastics, gardening and other things which might develop into postwar voce,tions or avocations for the wounded veteran. Through this sorvice were provided dellcate mechanisms which it would hove been impossible to obtain through regular hospital. channels. 75

In addition to the broadened scope of 1 ts corps, wartime pressure also brought about expansion of the routine Red Cross services. Foremost of these was blood doning, for which the national Red Oross mobile unit was in Martinsburg nine times. 76 The blood collected was shipped to Philadelphia where 1 t was made into plasma and sent overseas. A resistration booth was usually open two to three weeks head of time so thet donors might sign up for a certain time during the three-dey period.77

The process for each donor included three interviews, one by the staff assistents at the time of registration, another by the nurses aides at Calvary Methodist Ghurch in Martinsburg, where the donation was to be given, and a third by the person in charge of the moblle unit. Blood was taken by the doctor In charge; the donor was then fed by the canteen corps and in many cases taken home by the motor corps. The lunches, cost of which amounted to around seventy-five dollars, were donated each dey by some organtzation or individual, of ten in memorium. 78 Since public response to the blood donor drive was slow at first, the committee found It necessary to put on an extensive compaign. 
Dooperation was urged through movies, churches, radio, nowspapers, placards and other means. Many merchants soliclted in advertisements and window displays, in an effort to have 160 donors each day after the eliminating process had taken place. As a result of this campaign the quota was met each time except once, that fallure being due to an eplatemic of influenza. A total of 4080 pints was collected, and fiftyfour persons upon donating eight pints received the pin and certificate of the galion club. 79

Spectal note should be made of the full cooperation by the Interwoven Mill. Mill officials arranged that workers be let off on the days they volunteered to give blood. They also provided transportation, supplied iron pilis to the donors, and hired a nurse to chock on them occasionally after their return to work. 80

Fear was the impetus for a great deal of first-aid training during the early part of the war. All civilian defense traintng was turned over to the Red Cross. 81 state headquarters urged all alr rald wardens and others taking part in clvilian defense activities, as well as faotory and business personnel, to enroll in a first-aid course. ${ }^{82}$ Many who attended the classes were housewives. In this manner a knowledge of first-aid became more widespread among the people of Berkeley County than ever before.

Red Cross funds were raised by means of a drive in the spring and fall of each year with the exception of 1942, when the fall drive was not held but carried over and combined with the National War Fund Drive In March, 1943.83 Goals, which ranged from $\$ 7000$ to $\$ 24,250$, were exceeded in every case, sometimes by as much as $\$ 30000^{84}$ 
The Junt or Red Cross, bestdes meeting in knttting classes once a weak and contributing to the axmy and refugee garments, made articles such as smoking stands for Newton D. Baker. 85

Water safety had been a permanent pert of the Red Oross program since 1932, Its importance due mainly to several local quarries with very treacherous swimming conditions. The county program inciuded sending two persons each year to the national Red Cross Swiming Sohool for training qualified instruotors. During the summer months classes were held in the Martinsburg City Hall pool ranging in grade from beginning swiming to life saving. 86 These were discontinued, however, during two war years: In 1943 to help prevent the spread of a polio epidemic, and again in 1944 when the army took over the pool for hospital use. 87

Under the head of disaster preporedness a very detailed plan was worked out, with an organization set up to provide food, shelter, transportation, nursing and first-aid in case of an emergency. No emergency, however, presented itself. 88

Six clesses in home nursing were held by registered nurses during the early part of the war. 89 . The number dininished later as the already overworked nurses became almost impossible to secure.

The Red Oross also offered its services to parents who wished to locate and visit patients in Newton D. Baker, and was respongible for checking on illness in families for emergency furloughs. 90

An account of the Berkeley County County Ohapter would not be complete without mention of an outstanding personality in Red Cross, Mrs. Russell J. Bergen, whose record of service cannot be overlooked. In the nationel organization, Mrs. Bergen served on the rules of procedure committee for the national convention which met in Philadelphia 
In 1946. She was the only woman on the committee of ten seleoted to set the national Red Cross budget. A volunteer worker since 1921, she was chalrman of the Berkeley County Chapter from 1935 to $194 \%$, and has served on the board of directors since her retirement. Her wartime duties included the organization of all corps and serving as volunteer special servioes chalrman. To these tasks Mrs. Bergen devoted 18,200 hours. 91

The ducational System

On Monday, December 22, 1941, classes in Martinsburg High school were interrupted by three short rings of the bel1s. Students and teachers filed out of their classrooms, marched to the lower halls and lined up in double file. In two minutes another bell sounded the lallclear' and the students' first experience with an air raid alerm ended in an orderly manner. 92 similar drills were soon to be held in the other schools of the county, in preparation for the day of an actual attack.

Soon after the outbreak of war, State Superintendent of Schools, W. W. Trent, mailed a bulletin to the office of each county superintendent requesting that "victory" programs be organized in West Virginia schools to meet the lunusual problems before us and the new problems which will face us during the reconstruction. 193 The superintendent suggested that feeding and sleping facilities be mode avallable in schools in case of emergency: He adrocated extension of rocational tralning classes, especlalily in agriculture, and asked that home economics teachers work in cooperation with county nutrition committees to set up community centers in which to care for local people and refugees from nearby sections who might be made homeless in the event of an attack. 94 
In response to the state superintendent's recommendations, a survey was made in Berkeley Oounty of school buildings which might be used for quartering troops or evecuees, feeding capacities, avaliable cots, and other pertinent information. Results of the survey were forwarded to the state office of civilian defense and included in the State Survey of Avatiable School Faclitties for War Bmergency. 95 The county report is sunmarized in the appendix.

Also in response to the superintendent's suggestions, vocational egrioulture shops in the three Berkeley County high ochools were opened for evening classes. Information on the newest methods of scientific farming, pest control, fertilizers and other data from the Department of Agriculture and the experiment stations were in this manner made available to the farming public. Farmers who viahed to do so might bring equipment to these shops for repoirs. Many farmers found this service invaluable to their continued operation. 96

Community canning centers vere set up as part of the Hedgesville, Martinsburg and Bunker Hill school programs. Operating under the gupervision of the vocational agriculture instructors, the canneried were open several days and evenings a week during the canning season. Anyone might bring in produce or meats, prepare the food himgelf with the ald of a trained instructor and steam pressure equipment, pack it into containers and leave it to be processed. This now mothod, begides being efficient and Inexpensive (tho procossing fee was a few cents per can), provided the opportunity of companionship with other canners. The advent of the community canning center made such institutions as the home apple-butter kettle elmost completely a thing of the past. 
One of the chief contributions of the Berkeley County Bducationel gystem was the training of war workers. Close proximity to Washington, Baltinore and the Fairchild Alrcraft Plant in Hagerstown, Naryland, geve rise to the need for a specialized training program which was Instituted in the summer of 1940 one of the first in the United States. Through the National Defense Training School, located in the old high school bullding in Martingburg, a total of 1233 pupils were trained in welding, sheet metal work and auto mechanica. Most of these students beceme Fairchild workers, although some went to Glenn $I$. Martin and Bethlehem Steel in Baltimore.9?

In the high schools moxe emphasis was placed upon mathemetica and physics as preparation for service in the armed forces. Secretarial training also became a popular and important course and a great many girls from Berkeley County schools soon upon graduation became workers In Washington offlces. Enrollment in all the high schools dropped as boys (and some girls) of age left school to go into industry, to help at home, or to volunteer for military duty, 98 By May, 1943 , fifty high Bchool boys were doing full-time farm work and others were working on t. part-time basis. Under a state ruling of April 1 of that year, which permitted leaves of absence for such work providing they had passing grades, the students were given extra school credsts. 99

Twenty teachers entered the service and twenty more wont into war work. There was no real shortage, however, since many former teachers made their services available. Not over a dozen energency teaching certificates were issued during the war. 100

Graded schools, junior high and high schools alike participated In the salvage of tin and fats and in the bond and stamp sales. ${ }^{101}$ The 
The teachers of the county contributed more than ten thousand hours to the war rationing campaign. 102

In general, the school system was subjected to the same dislocations as any industry in wartime. Parts for busses, furnaces and other equipment became increasingly difficult to obtain; upkeep and supplies were curtailed; but after the endless adjustments and intensive planning necessitated by the war years the school aystem found itself with: a vital and a nore flutd program. 103

\section{Stote Cuard}

The national guard company serving Berkeley County is the descondant of a rether lllustrious ancestry. It has the distinction of being the second oldest militery unit in the Unfted States. Organized by Morgan Morgan in 1735, it has participated in every major struggle gince the French and Indian War. During the Civil War it was known as Company $F$ of the First Regiment, West Virginia Militia, one of the few regiments in the country with companies in both the Union and Confedorate Armies. Regimental insignia now carry both the blue and gray. In 1926 the First West Vixginia Infentry, having been reorganized, became the 201st Regiment, National Guard, and Oompany has since boen known as Company $D .^{104}$ Upon the outbreak of World. War II It was again mustered into federal service, sent to Fort Benjemin Harrison, Indiana, for further training and thence to Alaska. Iater it crossed the Pacific to teke part in the New Guinea and Philippine Campaigns. 105

Wh the state militias away, communities of this and othes states were left without proteotion. Governors of the respective states, in 
conjunction with the National Guerd Bureau, therefore, authorized the activation of state guard units. Governor Matthew M. Neely immediately issued an order providing for the formation of a state guard in West Virgtnia. 106 In Jebruary, 1942, Ad.Jutant General Carleton O. Pierce Instructed Bdgar M. Sites, of Martinsburg, to reactivate Oompany $D$ as an Infantry rifle unit in Berkeley County: Sites organized the company and it was officially recognized in March, with two officers, Sitos as Captain, B. Wood Rannels, First Ileutenant, and forty-two onlisted men. ${ }^{107}$ In August of that year Sergeant oec1l W. Wood was commissioned Second Lleutenant, supplylne the full complement of officers. 208

At least two local industries contributed material support to the unit. Some twenty-five to thirty blankets, factory rejects, were obtained from the Dunn Woolen Company for a nominel sum, while the Interwoven Mill furnished each member of Company $D$ with two pairs of socks. 109

The company arilited twice each week during the war yoars, using the armory in Martinsburg as headquarters. Its training achedule, while following the basio training of the regular army, lald particum lar emphasis upon guard duty, traffic control, bayonet practice, quelIing of domestic disturbances, rifle marksmanship, first ald and protection agalnst chemical warfare. During the helght of the war, weekend monuevers of some type were held every other week.' These included twelve-mile hikes with full fleld pack, bombing raids in which paper sacks filled with flour were used as explosives, and drill demonstrations on the Martinsburg High School athletic fleld depleting the dispersion of crowas. 110 
Company $D$ was equipped with bayonets, tear-gas, rifles and sub-machine guns. One case of emmunition was set aside to be opened only upon orders from the adjutant general in the event of an emergency. An instant mobilization plan was kept ready. 111 Blackout notices were releyed to the commending officer as soon as recelved by the local civilian defense office. Within flfteen minutes the company could be mobilized and performing its blackout function, that of guarding state and federal property. If, in case of an actual attack, an unexploded bomb should become imbedded in the surrounding territory, state guard Instructions were to maintaln a guard line around the plece where the bomb entered the ground until an army bomb expert could arrive to remove the detonator. 112

The unit did not participate but was alerted during the hurricane diaster at Shinnstion. It was called to active duty on ono occasion to help fight a forest fire in the northern section of the county. At the Martinsburg alrport the company guarded the Feirchild experimental planes brought there for trial flights. Some of the officers and noncormissioned officers were used in the training of army and navy reserve cadets studying avlation under the War Training Service at Shepherd Fizeld. 113

The age limit for the company was elghteen to sixty-two; physical examinations were waived during the war: One great contribution of this and other units of the atate guard organization was that of preinduction training to those who went into the national service. Men who went from the ranks of the state guard into the regular army found It less difficult to make the adjustment from civilian to military life and in many coses promotion was rapid. Of the thirty to thirty-five 
members of Compeny $D$ who entered the various branches of the federal service, all had good records and all emerged elther commissioned or nonconmissioned officers. .124

The local unit was represented at the staff school for guard offtcers held at Fort Knox in February, 1943, and November, 1944, by the gifth Service Command, and at summer training camps during the war years at Camp Dawson, Preston Oounty. 115 Company $D$ was chosen to put on the sield demonstrations at camp ${ }^{116}$ and recelved in 1944 special commendation for efficiency and services rendered from the chief of the National Guard Bureau of the War Department. Ileutenant Wood also received special commendation for services rendered during the summer training camp of 2944 from the army instructor and commanding officer of the West Virginia Military District, Oolonel John A. Bickel. 117

In 1945 Captain Sites was removed as captain and given active comand of the First Battalion which included Martinsburg, Morgantown, Falrmont and Kingwood. He was replaced as commending officer for Company $D$ by Iieutenant Rannels. Ileutenant Wood at the same time was made captain and placed on the general staff of the First Regiment as intelligence officer. This honor is mentioned because two such promotions had not previously been made from the seme county. 118

Adjutant-General. Plerce in June, 1945, received from Major-General John F. Willlams, acting chlef of the National Guerd Bureau of the War Department, the following comendation:

I have reviewed with interest the Annual Inspection Report of Company D, First Regiment, West Virginia State Guard, Martingburg, West Virginia, dated 2 Apri1, 1945, and especially the remarks of the inspecting officer: 
Whis is an Iixcelient unit. In the completeness and thoroughness of the training it is the best unit this inspector has inspected in the West Virginia State Cuard.

This is significant and I commend the officers and men for their interest and industriousness in malntaining an excellent unit. 119 
FOOTNOTES

CHAPMYR II

1 From an address by Dr. Henry T. MoDonald to the Martinsburg Kiwants Olub, December 31, 1941, The Martinsburg Journe1, January 2, 1942.

2 Mertinsburg News, August 21, 1942.

3 The Mert1nsburg Journal, December 21, 1941.

4 West Virginia State OCD Bulletin, December 11, 1941, War History Commission Records, West Virginia University Library, Morgantown (Hereafter referred to as WHOR).

5 Ibia.

6 The Martinsburf Journal, June 20, 1940.

7 Ib1a., December 11, 1941.

8 Ibia.

9 District Supervisors' Reports, January-February, 1942, OOD General Correspondence, $\mathrm{HHCR}$.

10 The Mart1nsburg Journal, December 31, 1941.

11 Martinsburg News, Apr11 10, 1942.

12 Ibid. Apr11 24, 1942.

13 The Martinsburas Journal, December 15 and 17, 1941 .

14 Ibid., January 12 and 13, 1942; Martinsbure Mews, Jamuary 12, 1944; OCD D1strict Supervisors Reports, January, 1942, UHCR.

15 The Mart1ngburs Journal, January 22, 1942.

16 Martinsbure Neys, May 15, 1942; OCD District Supervisors' Reports, May 23, 1942, WHCR.

17 Martinsbure News, August 14, 1942.

18 OOD Reports, March 9, 1943, $\mathrm{HHCR}$.

19 Martinsburg Nows, July 7, 1943.

20 Mountaineer Defense, september 13, 1943.

21. The Martinsburg Journal, December 15, 1941, January 5 and 8, 1942. 
22 Distriot Supervisors Reports, Jenuary-February, 1943, OCD GeneraI Correspondence No. 2, MHOR.

23 The Martinsbure Journal, December 20 and $23,1941$.

24 Martinsburg Nevs, August 21, 1942.

25 Mountaineer Defense, August 30, 1943.

26 Ib10., Bebruary 1, 1943.

27 Interview with $\mathrm{C}$. W. Wood, who attended the school.

28 Mountaineer Defense, February 15 and March $15,1943$.

29 OCD Files, August 11 and September 18, 1943; WHCR: Mountaineer Defense, June 21 and November 8, 1943.

30 Martingbure News, June 12, 1942.

31 Ibld., August 28, 1942.

32 Mountaineer Defense, August 31, 1942.

33 Martingburg News, September 18, 25 and October 2, 1942.

34 Ib1d., October 9 and 16, 1942 .

35 Ibid., October 16, 1942.

36 Ib1d., December 18, 1942.

37 Ibid., November 5, 1943.

38 Minutes of CD Supervisors' Meet1ng, March 2, 1943, MHOR.

39 Mountaineer Defense, March 15 and August 2, 1943, March 13, 1944.

40 Distrlct Supervisors Reports, January-February, 1943, OCD General Oorrespondence No, 2, WHCR.

41 Martinsburg News, March 12 and December 17, 1943, March 13, 1944.

42 The Martingburg Journal, January 15 and 19, 1942; Martinsburg News, November 24, 1944 .

43 West Virginia Blue Book, 1945, pp. 621, 623.

44 The Martingburg Journal, December 17, 1941.

45 Ibia., December 22, 1941 .

46 Ibid., December 18, 1941, Jnnuary 5, 1942. 
47 Ib12., January 5, 1942.

48 Ibid., Eebruary 7, 1942.

49 Martingbure Hews, August 1.1, 1942.

50 Ibid., September 10 and October 29, 1943.

51 Records of the State Dtrector, Treasury Department, U. S. Savings Bonds Division, Charleston. Iist of quotas and sales in Appendix.

52 Martingburg Nows, July 9, 1943; Mountaineer Defonse, July 19, 1943.

53 Ib1d., July 9, 1943.

54 Telephone interview with 0. Granvilie Smith, June, 1947.

55 Martingburg News, August 6, September 3 and 10, 1943; March 3, 1944.

56 Ib1d., October 1, 1943; March 3, 1944; interv1ew with C. G. Smith.

57 Martinsburg jews, November 26, 1943.

58 Ibid., Januiry 21, 1944; interview with O. G. Smith.

59 Marttnsburg News, January 19, 1945.

60 Interview with 0. G. Smith.

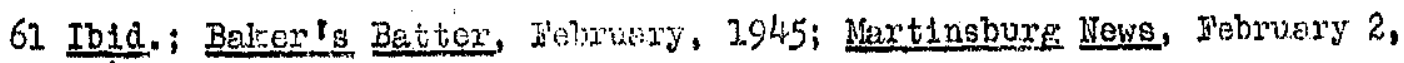
1945.

62 Personal intervlew with Mrs. Fussell J, Bergen, Chuirmen, Berikeley County Chepter, Red Cross, June, 1947.

63 Ibid.

64 Ibid.

65 Ibid.; The Mortinsbure Journal, Jailuery 3, 8, 12, Bobruary 3 and October 2 , 1942 .

66 Interview with Mrs. Bergen.

67 Ibid.

68 Ib1d.

69 Ib1d; Martinsburs Newg, No vember 22, 1942; Mounteineex Defense, March 15, 1943.

70 Personal interview with Bdgar M. Sites, whose wife was Centeen Corps Chairmen; Martinsburgi News, April 10, 1942, March 5, 1943. 
71 Interviev with Mis. Bergen.

72 Ibid.; Martinsburg Newg, January 19, 1954.

73 Miss May Taulkner.

74 Interview with Mra. Bergen.

75 Ibid.

76 Martingbure News, June 18, September 11, December 3, 1943; February 18, July 14, August 15, 1944; January 5, March 2, June 15. 1945.

77 Telephone interview with Mrs. Harry I. Reaves, Chairman, Blood Donting Service, June, 194 ?

78 Ibid.

79 Martingburg News, February 2, July 6 and 20, 1945.

80 Interview with Mrs. Reaves.

81 Ibla.

82 OOD Medical Division Memo No. 1, October 27, 1941, WHCR; The Mart1nsburg Journal, December 11, 1941, and January $2,1943$.

83 Martinsburg News, January 29 and Jebruary 26, 1943.

84 Interview with Mrg. Bergen.

85 Ibid.

86 Martinsburs News, June 18, 1943.

87 Interview with Mrs. Bergen.

88 Ibid.

89 Ib1d.

90 Ibia.

91 Ibld.

92 The Martingburg Journel, December 23, 1941.

93 OOD General Correspondence No. 2, MHOR.

94 The Martinsburg Journal, December 24, 1941 .

95 State Survey of Arallable School Facilities for War Mmergency, March 28, 1942, OCD Genera1 Correspondence No. 2, WHCR. 
96 Martinsburg News, April 16, 1943.

97 The Martinsbure Journal, January 5, 1942, and personal Interview with G. Williem Ropp, Superintendent of Berkeley County Schools, June, 1947 .

98 Inrollment in the Berkeley Count public high schools was 1290 in 1940-1941, 1200 in 1941-1942, a 6.97 percent decrease. West Virginla Educational Bulletin, Vol. $x_{1}$ No. 2, September, 1942.

99 Martingbure News, May 21, 1943.

100 Interview with $G$. William Ropp.

101 The Martinsbure Journal, December 12, 1941.

102 Interview with G. William Ropp.

103 Ibid.

104 Historicel Annua.1. National Guard of the State of West Virginia, 1938, pp. 61, 110.

105 Personal interview with H. M. Sites, Coptain, Oompany D, June, 1947.

106 Office for Emergency Management, Division of State and Local Oooperation, Washington, D. O., Supplement No. 7, Apr11 21, 1941, WHCR.

107 Martinsburs News, March 27, 1942.

108 Mountaineer Defense, August 2, 1942.

109 Personal interview with C. W. Wood, Second Lieutenant, Company D.

110 Martinsbure News, September 18 and November 6, 1942; May 14, 1943.

311 Ib1d., June 5, August 7, 1942.

112 Interviews with H. M. Sites and O. W. Wood.

113 Ibid.

114 Interview with E. M. Sites.

115 Martinsburg News, July 30, 1943; August 11, 1944; June 22, 1945.

116 Ibid., Angust 11, 1944.

117 Interview with E. M. Sites.

118 Ibla.; Martinsburg News, July 6 and September 14, 1945.

119 Martinsburg News, JuIy 15, 1945. 
CHAPTER III

INDUUSTRY

Asiculture

Of the approximately 202,240 acres of land aree in Berkelay County, 148,806 acres, or 76.3 per cent is utilized in farm production. This land is divided into 1338 ferms, averaging 111.2 acres in size and with an average value of $\$ 60.27$ per ecre. Most farm operations in Berkeley oounty are diversfifed, relsing a veriety of products primarily for sale, fruit orchards are the most numerous, with derying and livem stock production ranking second and third in importance, In 1940, 2323 persons were engeged in farming, making it the largest industry, from the standpoint of number of employees, in the county. ${ }^{1}$

The chief agricultural coordinetor is the county agent, appointed by the West Virginia Agxicultural Extension Service. The county extension organization consists of the County Jarm Bureau and eight community clubs, the presidents and secretarles of which compose a Harm Burean executive compttee with representatives from all communtles. It is thus a well informed body and from its discussions and rocommendations the county agent builds his general yeorly plan. 2

Sfter the outbreak of war, emphasis and activities of the county organization shifted away from projects such as cooperat1ve buylng and selling and the central theme became one of wartime adjustments. ${ }^{3}$ It was no longer a matter for theoretical discussion but of vital Importance that production be kept as high as possible, yet without greatiy 
depleting the soll. Studies and expeximents must be mede with new typer of fertilizers since many of those used heretofore contained materials necessary to the war effort and their availability would soon be curtailed. 4 Through pemphlets, newspaper articles and talks to meetings of farm organizations, County Agent W. N. Moclung and his aldes urged formers to cooperate closely with the Soll. Conservation Service. Typical of the methods stressed by these leaders was that of using the same amount of fertillzer on fewer acres of the best land so thet, regardiess of the length of the war, erosion and intensive production would not leave the soll depleted. 5

Special attention was given to the saving of all crops produced Farmers vere posted on methods of adapting old machiners to now uses as well as those of using labor more efficiently. A new machine for husking corn on the stalk was introduced as a labor saver and came into popular use during the war. In the fleld of horticulture organized assistance was given to growers as to the proper practices in soil building, fertilization and cover crops, resulting in a larger fruit crop than would hove been possible ordinarily under the same clrcumstences. A similar program pertaining to livestock was equaliy effective in bringing about an increased production of eggs, milk and meat during 1942. 6

Early in the first year of the war, several new committees were organtzed in the county to cope with the rapidiy arising problems. Farm machinery was allotted by a Machinery Ration Board. Establishad under the direction of the United States Secretary of Agriculture, this group was headed by the county chalrman of the Agricultural Adjustmont Administration? and consisted of three farmers and the county agent, 
who served as secretary. The boord met at regular interve, ss and apportioned according to the farmers' needs the pleces of equipment allocated to the county. 8

The AAA Chalrman was also named by the Secretary of Agriculture to head the County War Board. This group was composed of the local representatives of governmental agencies in the county: the Farm Credit Administration, the Fedoral Securfty Administration, the Soll Conservation Service and the Extension Service. As an overell advisory group it helped locate and make arrangements for essential supplies? The main function of the board, however, was that of providing a means of cooperation between farm people and the selective service board in recormending deferments. Much time and effort were deroted to this and the draft board cooperated well. 10

As the labor problem became increaslngiy acute, a locel organization, known as the Berm Iabor Sub-committee, was set up for the purpose of cooperating with state and federel emergency farm labor programs to provide facilities for housing and feeding lmported workers and determining wage scales for plece work, particularly in the harvesting of apples. This organization, which later developed Into a legally Incorporated agenoy known as the Fastern Panhandle Fruit Growers' Association, contacted every avallable source of outside help, and through its efforts and job of harvesting fruit and farm crops was greatly facllitated. 11

Heads of locel undustrial plants cooperated by urging workers to take farm jobs after hours and. much part-time help was secured. in this manner. A local publicity campaign with the theme "Let's pick our own apples !" brought many people into the orchords who 
would ordinerily have bought their apples already picked. The WPA and the United States Fimployment. Service turned all available help over to the farms. A great deal of work wes done by school chlldren and the board of education approved a plan, never used, to close the schools entirely if the necessity arose. 12

Publiclty from the varlous ferm organiations and cooperation from other agencies resulted not only in larger all-round production during 1942 but lald the basis for the "all-outl effort of 1943 . It also helped a number of carmers make the necessary adjustments without which thelr farma would have changed hands or shortly ceased product1on. In spite of all this the outlook at the close of the first year of the war was gloomy. The county agent wrote:

Never has there been a time, in my experience, when so many farmers were faced with the job of making adjustments in their farming business if they were to keep on operating.... Fach farm presents its own particular combination of problems. 13

Most farmers who remalned on their land were willing to do everything possible to produce food in the increased quantities so vitally needed for the war effort if they could be sure their crops could be harvested, so that by producing they would not be causing themselves finenctal loss. It was this fear, however, that caused many farmers to plan their operations according to the supply of rellable and skilled help available. To this end the Har Board worked in cooperation with the selective service board, furnlshing complete information on cases of agricultural deferment. On the strength of this information, agricultural deferments were granted to nearly five hundred farm men and boys. This was one grent stabilizing factor in the problems of food production. The Berkeley Oounty Wartime 
Transportation Comittee worked with the Har Board to get certiflcates of war necessity and the gasoline necessary for non-hlghway work. ${ }^{14}$

Almost a third of the crop land of the county is set in tree frults. Of these nineteen-thousend acres, elghteen thousand produce apries and the rematining thousand, pegches and cherries, The 1.944 crop totaled 1,350,000 bushels of apples, 150,000 of peacies and 40,000 of cherries. This yield was approximately a ten year average. 15

Two schools in job instruction for orchard foremen were held In February of that year as in the previous winter and wore wellattended, which made for botter handing of inexperienced help. Becauge of good weather and the help of 150 to 200 wonen, boys and girls, the cherry crop was hervested with very little loss. Many cherry workers moved on into the peach picking season and that crop was harvested by local workers with the exception of sixty high scinol age boys, brought into the county with adult foremen, by the Extension Service. 16

The big job, hovever, was harvesting the apple crop. The farm labor sub-comittee began early in the year to investigate possible sources of labor. When the committee in mid-summer becane incorporated as the Fastern Panhandle Frult Growers Association, 1ts first move was to raise aboitt $\$ 9000$ to repair a deserted livestock auction building in Mertinsburg: ${ }^{18}$ By September 18, 334 Barbadians had been moved in. The start was discouraging: bad, rainy weather prevailea in september and october; the work of handing the long ladders and picking apples without bruising them was new and diffcult. In October an epidemic of mumps broke out, this disease also now to the men. As natives of a semi-tropical clima,te, they were 
bothered by cold mornings; some day's more than half stayed in camp. However, when the season ended in mid-November, the men had picked about 430,000 bushels of apples, earning thenselves about $\$ 3,000$. Growers admitted that in spite of the trouble and confusion, the Barbadians had saved the apple crop. ${ }^{18}$

In the spring of 1945, with the labor outlook still extremely bleak, the Fruit Growers' Associetion, working through the War Hood Admintstration, opened a camp of one hundred Jamaicans. Of these, forty-two refused to work and were sent home, the plan being to replace them latex and to secure three to four hundred more for harvest time. The apple crop, however, was reduced to about one-third by killing frosts early in May. ${ }^{19}$ Production worls could then be handled by local help, and so on May 12 the Jamaican camp was closed and the men returned. 20

Beceuse of the freeze the 1945 sour cherry crop was ebout twentyflve per cent of full production. Plcking was done by lockl help-women, boys and girls. Local women and chllaren also thinned paches. A vigorous campaign was put on to recruit peach pickers. Extension service aid prevented crop loss here by recrutting about fifty boys in other parts of the state and bringing them in to help with the plcking. 21

Much of this year's small apple crop went to the processing plants. Many growers sent their entire crops and did not operate packing houses at all. This provlded more labor for pioking and moving the crops, but outstde help was still needed. Through the cooperation of officials at Newton D. Baker General Hospital, the Truit Growers' Asgociation 22 succeeded in opening a camp of 
seventy-five German prisoners of war on the hospltal grounds. Others ceme later to make a total of 134. These men supplied the adaitional help needed to harvest the apple crop without 10ss, prune, clean up the orchards and catch up on other beck work. Since the corn harvest was far behind schedule some prisoners were set to cutting corn and fllling silos, and while the advent of bad weather found some corn still standing in the flelds, the largeat part of the orop had been safely stowed away. 23

Many farmers were agreeably aurprised at the cooperation offered by the German prisoners. Most of the men were apparently well acqualnted with nearly all types of farm work, and were industrious to the point of staying overtime in several instances to repair a broken machine. With the exception of a few who were still arrogantly Naz1, the farmers had high praise for their German workers. 24

The war brought about a profound change in agriculture in Berkeley County. As a result of united attempts to increase production, the row-crop type of small farm tractor replaced horses almost entirely. Other types of labor-saving machinery were bought by farmers as they beceme avallable: stde-delivery rakes, hay loaders, pick-up ballers, forage harvesters, corn pickers, corn biaders; and all manner of implements such as plows, cujtivators and disos. This county and a few along the Ohio River received practically all the farm machinery allotted to the state, so that the county went almost from horse to power farming. And there was, as a direct result, a tremendous increese in production of food. 25

Much custom work was done, machinery being allotted many times on that basis. Nearly anyone who obtained a plece of equipment 
arranged to keep it in use throughout the season. There was a great increase in electr1c1ty for labor-savine, motor driven devices used on farms. There was also much extension of power lines to sufficient size farms. For example, a farmer might obtain a lo0-foot extension for every milk-producing cow he owned. The government made a special effort to increase milk production. When the war began there were very fow mechanical milking machines. When it ended practically every farmer had one. 26

In order to keep equipment in good working order at a time when Its manufacture was so sharply curtalled, three farm machinery repalr shops were set up by vocational-agriculture depertments in the high schools and two by the farmers themselves. At these shops welding might be done, parts replaced and other repairs made woll anead of the time when a breakdown might serfously dismupt production. 27

In addition to power forming, the use of a three-fold program advocated by the extension service and the war board was a second important means of stepping up production per acre. Farmers were informed, through bulletins, talks and newspaper articles, as to newly-developed, higher producting strains of grain. Information concernine new chemicals avallable for use in pest and disease control was dissemineted in the same manner. Finally the farm leaders stressed proper fertilizetion. If, they sald, the farmer would Increase his expenditure for fertilizer, the not proflts would be far greater in proporition. 28

The three phases of this plan vere emphasized in partioular Wh respect to corn, with the result that hybrid corn increased during the war period to from twenty to eighty per cent of the total 
crop, and corn production in a since been going steadily u pward, 23

The need for increased production of livestock led to a special effort to eradicrte diseoses. Fermers were urged to vaccinate for cholera and black leg, to cull out antnels no loneer useful for rilk production or breeding purposes and to take steps to reduce loss from diseases and parasteg which had formerly received slight attention. Ihis progxcin brovght about an impoovement in the general standards of livestocle production. 30

The campaign to get every femily to erow enough food for its own use and a littie extra was promoted through meetings, novies, and canning demonstrations. Information wes made oveliable on pregervetion of food in brine and by dehydration, nethods of producing, and determining amounts needed for home use. ${ }^{31}$ The program mot with enthusiestic cooperation. More than one hundred persons attended the garden school conducted in Martinsburg early in 1942 under the auspices of the Department of Cooperative Extension Work in Agriculture and Home Economics. Tixtension workers from West Virginia University gave 11lustrated lectures on plent diseases and pest control, preparing a garden, and production methods. With less fresh food avaliable, they pointed out, due to war transportation and labor afficulties, and to reduce the cost of living as well as increase the nutritional velue in the diet, every family was urged to have a garden. ${ }^{32}$ At this and subsequent sohools, extension service bulletins covering nearly every phase of the subject were made avallable so that each person might find holp with his own particilar gardening problems. 
In Martingburg there was good response to the victory garden program, ${ }^{33}$ al though the drouth during the first year, which reduced production to nearly helf, discouraged many. Beglnuing in 1943 the Juntor Board of Prade sponsored a plan whereby the city was divided Into zones and a board of locel. agricultural experts anpointed to hold meeting's at schools located in the verious zones. 34 gridently no production records were kept, nor would they have been impressive; but the vegetables growing in smell. plots of ground throughout the city indicated a widespread interest in the project. 35

Many famllies in the smaller communties began to raise more of their own food. eepecially mert. Some obtained stand of bees to produce the honey which would stretch their scent sugar supply. Special allotments of sugar for home canning encouraged the houseWife to preserve everything possible so that nothing might go to waste. 36

Froof of the fact that both urben and rural families were conVinced of the necessity to raise more food may be seen in a statement Issued by local chain stores and Independent grocers in 1943, to the effect that oanned garden products were not moving so rapidiy as in former years. This was true in particulor of beans, tomatoes and $\cos n .37$

Thus did. agriculture in Berkeley County meet its wartime chellenger. The county was fortunete in having able agricultural leadership during this critical time.

\section{Baltimore and ohio Railroad}

The industry in Berkeley County with the greatest war potential and having the moat alrect connection with the national war effort 
wos the Baltimore and Ohio Rajlroad. At the outset, B \& 0 officiels, realizing that regulax clvilian travel. would soon be supplemented. by thousands of servicemen and defense workers, besides the great quantities of wer materiels to be transported, began to make ready a.1. available equipment for service. ${ }^{38}$ Soon they were to find every faclilty of the whole system taxed to the limit. 39

Within six. weeks after Pearl Harbor, 600,000 troops had been moved by the railroads of the nation. This was, according to $B$ \& 0 Fresident R. B. White, the "largest single orgenized military movement in our history. 140 Nearly twice as many troops were moved in the United States during the next two months. In March, 1942, all

$B$ \& $O$ freight cars averaged $45.5 \mathrm{mlles}$ per day, an all time high. 41 Before the end of the war this record wos to be broken many times. By 1944 frelght traffic was 122 per cent above that of 1939 and passenger traffic was 324 pex cent above the seme prewar level. This tromendous increase was accomplished without a corresponding increase in the number of passenger and freight cars and with approximately the same number of Iocomotives as in 1939.42

In addition to the troop movements which passed through the county, the rallroed, after the opening of Newton D. Baker Hospital, brought the wounded In from the ships as they docked in Norfolk and other ports. A spur of the main line provided service aireot to the hospitel. 43

The main wartime importance of Berkeley County to the $B \& 0$ Railroad ley in its storage yards located at Cumbo. From April, 1942, to the cloge of the war a totel of 7000 carloads of war materials was shipped to the Cumbo Yards direct from the manufacturing 
plants in thio storace arna. Ilere it was stored, to be released as ohipo beceme avedloble in the enotern sogporto, 44

The innovetion of the World. Wer II storece yards was a marked Improvement over provious methoda of aupply for two reasons. The Lact that materfaln were not stored nt the factorles but were moved as quickly as they wore turnd out hind a favorable effect on morele, and indrectiy, on production at the plants. Wheress in World War I the yards vere funl of curo which sat loaded mile few wore available for shipplne, tile now syatem provicod on orderly movement and prerented shortages of equipment. 45

Bor every man who took part lis a laiding on onemy territory, flve to ten tono of supliseo wore required. ${ }^{46}$ The two most important Items of equipment stored at Cumbo during tine early pert of the war vere rallway cars and alrolane loundins, unts. The cars were stored knocked down' ready to be ansembled $u_{1}$ on arrivel at their destination. Phis destination, accordinf to lock 1 rallroad offiolals, was the Mdalle Dast. Hero they wore to bo put to une by the rallroad which wallt during the war from the porelen Gulf to Tehoren for the purpose of hauling, supplies to the Rusolong. The landing mats, mado of steel. links, could bo unrolind and foined to form landing strips on the sandy beaches of the South Pectfic. Smoller amounta of other equipment such an plpe of all kinda, bromide and other chemlekl warlave materials, and such rallrood equipment as asphalt, piling, orossHes and machine trucks were also stored at Cumbo Yards. 47

All orders were handled by code number. When markings grew confuging code schemes were changed, unt1l flnelly a gystem of colors vab adopted to Indicente alfferent types of equipment. Thus, whether 
a shipment was bound for the war zone in Italy, Africa or elsewhere, the reciplent was able to understand and differentiote between, for exampie, cases of machine guns and those of typewriters. The local office never had a bill of lading returned. Both railroed officials and the government were pleased with the way in whoh the equipment was handled. The appreciation of the latter was expressed in a letter of commendation from the War Department. 48

\section{Iirestone Industry}

Prectically all of the limestone produced in West Virginia is found in the Eastern Panhandie, more specifically in Berkeley and Jefferson Dounties. During the prehistoric ages of the great inland seas this deposit wos formed by the collection of layer upon leyer of shells and the skeletons of sea animals into $a$ vast bed one hundred and more feet thick which biseots Berkeley County and extends north with the Appalachain Mountalns to Pennsylvenia and south into Virginia. The stone in this belt, known as the Mosheim formation, is almost pure (ninety-seven per cent) calcium carbonate. 49

Because of its puxity the Mosheim limestone is the best substance known for use as flux in the manufacture of steel. About seventyfive per cent of the total production is shipped directiy from the mines and quarries to steel mills in the New Ingland States, the Pittsburgh area, Baltimore and the deep South. One thougand to 1500 pounds of stone are required in the production of a ton of ateel. 50

The largest of the several Iimestone operations in Berkeley dounty is the Standard Iime and stone Company, located south of Martinsburg on Route Nine. In adaition to the rew stone, which is 
graded to snit the verlous methods of steel production, two other basic products, lime and cement, are put out by the Standard plant. The Iime manufactured here is used in the compounding of certain drugs, as a chemical in woter purification plonts and. in other chemical processes. It also has some uses in the steel industry and, after hydration, is widely used in aericulture and in the manufacture of masonry morters, which compose the third basic product. 51

At the beginning of the war standard employed a total of 550 men. This flevre, due to aroft calls and the migration to defense plants, dropped steadily during the wor years to a low of 344 in July, 1945.52 This loss of manpower, with the corresponding increase In limestone demand by the steel mills, for a time threatened the efficient operation of the plant. The situation wes remedied somewhat, however, by increesed mechanization of two types, both of which made possible more stone production per man-hour. The installation of larger crushing equipment allowed the use of slower explosives, breaking the stone into larger pleces. This provided a greater yield of the larger eight-by-five inch open hearth stone, the type most in demand by the steel mills. The second factor, conversion from track to diesel trucks for underground haulage, cut down on personnel formerly needed in the maintenance of track and alukeys, and at the same time provided far greater flexibility of operation. 53

\section{Textiles}

The textile industries in Mertinsburg have for nearly half a century made up a large portion of the county's economy. However, 
since the close of World war II two of the plants discussed in this section have ceased to operate. The Benkeley Woolen Compeny closed in 1949,54 a victim of the shift in demend from pure woolen goods to those of the newer synthetic fibers; and early in 1953 the Dunn Woolen Company became the second "casuelty of changing conditions. 155

Dunn yoolen Company. The Dunn Company, conslsting of the main plant at Martinsburs and subsidiary plants at Bunker Hill and Middoway, Jefferson dounty, worked entirely on government contracts from the beginning to the end of the wax. During the first two and a half years its looms produced twentymounce olivemarab sulting for makine unfforms and the heavy thirty-two-ounce overcoating--over a milion yards of each. 56

The army quartermastex-general in 1943 informed company offlcials of a shortage of blankets. This was entirely new product for the local mill. Nevertheless 800,000 to a million blankets were woven. The Berkeley Upholstering Company, closed for the duration, was rented by Dunn officials and here tables were set up for cutting and finishing the blankets. 57

Becuuse of its high-priority rating the company had no trouble obtaining repair parts ${ }^{58}$ and lost only thirty of its 528 employees during the war years. 59

Berkelex Hoolen Company. The Berkeley mill at Martinsburg, a branch of the main plent at Winchester and a slightly smaller operaation than Dunn, also switched entirely to war production, manufacturing cloth for axrny ocercoats and uniforms. Beginning Hew Yearis Day, 1942, both mills began working on a twenty-four-hour day, sevenday week basis. 60 This was the very critical poriod in which 
thougands of men were being inducted into the armed forces and uniforms were necessary with which to outfit them. After four months of continuous operation, the mills wexe able to return to a five-day week, sti.1 running twenty-four hours a day. 61

Berkeley also filled government orders for army blankets. During the last year of the war, ebout fifty per cent of its production was military and the remainder, civilian goods. 62

Perfection Garment Corapany. The Ferfection Garment Shop and its branch plants in Charles Town and Keyser ordinarily limit themselves to the manufacture of women's house dresses, pajames and vork uniforms. An exception was made durine the war when the Martinsburg plant filled two types of government orders. About 25,000 dozen each of sesrsucker sllps were produced to be sent to Europe under the Lend-Lease program, and cotton shorts were made for the men in the United States Navy. The latter were sent to various navy quartermaster depots. 63

Some wartime shortages of thread, repair parts and needles were felt, but had no serious effect upon the operation of the plant. 64 Imployment dropped from 395 in December, 1941, to 230 in July, 1945. most of these being women who went into defense work.

Interwoven stocking Company. Interwoven is the largest exclum sive menufacturer of men's hosiery in the world. From the Martinsburg plant direct to the retailer are sold over $2,000,000$ dozen pairs of socks a year. Subsidiary plants are locoted in Hagerstown, Maryland; Berkeley Springs, West Virginia; and Morristown, Tennessee. All production from these smaller mills comes to the Martinsburg plant where it is dyed, finished and boxed for shipping. A million 
dozen pairs are kept in atock so that all orders may be filled instantiy. 66

During the war, about twenty per cent of the total production was under groverument contract. The company manufacturea $12,374,000$ pairs of socks for the army and navy. These were of cotton, wool, and a new type known as the cushion foot, developed by Interwoven. The latter had a heavy terry cloth sole, particularly useful in the tank corps or wherever heat was intense on the feet. It was adopted by the army as a standard type of sock. 67

Yarne for the manufacture of civilian socks in wartime were restricted to cotton and rayon. From a total employment of 1707 in December, 1941, ${ }^{68} 204$ men and women went from the Martinsburg plant into the service. Company offictals menaged to fill in, mostly with women, so that there was no labor shortage. As an essential industry it was able to defer enough mechanics to keep the machinexy in good repair and see thot proanction was not interrupted. 69

\section{Frutt Products}

The apple processing plants in this section came into.being as a result of the national tendency toward buying food in cans. It was encouraged by the growers who, particularly after the loas of the European export markets in the 1930's, turned gradually awey from the practice of grading and fancy packing, when often the sale was uncertain. The trend in recent years has been for the grower to contact one or more of the processing plants during the growing season and then to deliver the entire cxop in bulk, just as it comes from the orchards. The introduction of canned apples in all forms 
has proved exceedingly popular. This type of product has largely replaced in food stores the practice of selling apples in bushel, half-bushel or peck contelners. The modern housewife finds that With Iimited time and storage space avaliable, the purchase of apples already prepered for use is convenient, and usually less waste is involved.

National Fruit Products Company. The main Hational Fruit plant is 1000ted in Winchester, Virginia. At Its Martinsburg branch the primary products have been apple julce and vinegar. Prune juice was manufactured here to some extent durfing the war, but the process was later stopped due to the expense of bringine in the fruit. Apple juice becare a popular product in wartime. Iaree quantities were sold to companies who, because of restrictions on sugar, bottiea tie juice to sell as a substitute for soft drinks.

Although the labor situation was nover serious, expected shortages Ir 1944 and 1945 were alleviated by lmporting some thirtir to sixty Germon and Russian prisoners. These men were brought here by bus from a camp in Wirchester. The kussians appear to have been formex Germen captives who had been placed on the German front lines in labor battelions: 71

Q. II. Musselman and Company: Located at Inwood, the Berkeley County branch of the Musselman Compeny is larger than the home plant in Biglerville, Pennsylvania. During the war some vinegar was sold to the government from the Inwood plant. Its mein product, however, was applesauce, much of witch was eventually shipped overseas. 72 Some cans were given a tpro-coat, I a protective coating of olivemab color paint to keep out moisture which might penetrate and rust 
oons stored in the darnp atmosphere of the holds of ships, or unloaded and stacked in tire jungles. At times it was found necessary to toss crates of the cens overboard to be carried ashore by the tide. A crescent printed on the lobel of each crate was an international symbol Indicating a food product, and practically insured that its contents would be salvaged by natives. Tor shipplng conditions such as these, a special type of carton was developed. Made from hard flbers and put together with spectal resinous glues, these cases vere completely waterproof, so that the tin cans they contained would never rust. 73

In 1944 some of the Russtan prisoners were obtained to supplement and supply of labor, and the following year some work wa done by German prisoners of war stationed at Newton D. Baker Hospita1.

A Musselman product was involved in an incident releted by $a$ Berkeley County man who had been in civilian life a truck driver for a local orchardist. During the Italian Oempolgn he took pert in the fighting around Cassino. The private, detailed to carry supplies from the road to his company's less acessible position among the hilis surrounding the ofty, was startled to find among the supplies a case of Musselman's applebutter. Immediately there came to mind scenes from a remote and less turbulent time when he might have hauled these very apples to the Inwood glant. He sat down and wept beside the carton of applebutter. 


\section{FOOTNOTES}

GHAPTER III

1 United States Consus of Agrlculture, Virginia and West Virginia, 1945, Vol. I, part 15, pp. 212, 232 and 300; Personal interview with Vernon Armbrester, Vocationel Agriculture Teacher, Hedgesville High School, Tebruary, 1953.

2 Amual Narrative Report of the County Agent, Berkeley County, West Virginia Agriculturel Bxtension Service, 1941. Hereafter cited as Annuel Warrative Report.

3 Ibid. 1941 and 1942.

4 Maxtinsbure Newg, December 31, 1942.

5 Annual Harrative Report, 1942.

6 Ibia.; and Mortinsbure News, February 27, 1942.

7 James I. Dillon, Hedgesvilile fermer.

8 Martinsburg Hews, January 6, 1942; and personal interviev with W. N. McClung, County Agent, June, 1947.

9 The Martinsburs Journal, January 30 and Bebruary 4, 1942.

10 Interview with W. N. Moclung.

11 Ibia.

12 Annual Narrative Report, 1942; Martinsburg News, Apr11 24 and Ju1y 10,1942 .

13 Annual Narrat1ve Report, 1942.

14 Ibid., 1943; and Martingburg News, October 23, 1942.

15 Anmual Narrative Report, 1944.

16 IbIa.

17 Martingbure Nevs, August 25, 1944.

18 Annual Jerrative Report, 1944.

19 Martingburg Newg, May 4, 1945.

20 Annual Harrative Report, 1945.

21. Ibia. 
22 Martinsburg News, June 23, 1944.

23 Anmal Narrative Report, 1945.

24 Interviews with W. N. McClung end C. W. Wood, farmer.

25 Interview with H. N. McClung:

26 Inja.

27 Ibid. and the Martinsburg Journgl, December 16, 1941

28 Interviews with W. N. MCClung and Vernon Armbrester.

29 Ibia.

30 Ibla. and The Martinsburg Journal, January 9, 1942.

31 The Martinsbure News carried an article on victory gardeniug in every wartime 1osue.

32. The Mertinsbure Journal, Januery 30, 1942.

33 Martinsburg Hows, February 13, 20, March 6 and 13, 1942.

34 Ib1a., March 26, Apri1 16, 1943.

35 Personal interview with Edgar I. Henshaw, Ration Board member, June, 1947 .

36 Interview with W. N. McClung:

37 Anmuel Narrative Report, 1943.

38 The Martingburg Journe1, December 22, 1941 and January 6, 1942.

39 Personal irterview with J. G. Tonry, B \& 0 Yardmaster, Martinsburg, June, 1947 .

40 Mertinsburg News, September 4, 1942.

41 Ibid.

42 Ibld., January 5, 1945.

43 Interview with J. G. Tonry.

44 Ibid.

45 Ib1a.

46 Martinsburg News, January 5, 1942.

47 Interview with J. G. Tonry: 
48 Iojd.

49 Robert 0 . Brand, Limestone Production in Hest Virginia, printed copy of a speech presented to industrial Minerels Division, American Institute of Mining and Motellurgicol Engineers, September, 1951. Obtained through the courtesy of R. O. Brand.

50 Ibld. and personal interview with Robert 0 . Brand, of the Brend Ingineerjing Company, Martinsburg, February, 1953.

51 Interview with R. O. Brand.

52 Bmployment Survey, Martinsburs and Berkeley Oounty, by the Martinsburg Chamber of Commerce, 1941-1945. Fereafter cited as Bmulorment Survex.

53 Interviow with R. C. Brand.

54 Telephone interview with R. C. Williams, former Manager, Berkeley Woolen Compony, Eebruary, 1953.

55 The Martinsburg Journat, February 19, 1953.

56 Personal interview with Garland. I. Dunn, Vice-President, Dunn Foolen Company, February, 1953; The Martinsbure Journa1, December 31, 1941, January 3, 1942, and June 4, 1943.

57 Ibia..

58 Ibie.

59 Employment Survex, 1941-1945.

60 The Martinsburg Journa1, January 3, 1942.

61 Interview with R. C. Wiliams.

62 Ibid.

63 Interview with John R. Poland, President, Perfection Garment Company, tebruary, 1953.

64 Ibja.

65 Ibid. and Bmployment Survey, 1941-1945.

66 Telophone interview with Bennett Taylor, Personnel Manager, Interwoven Stocking Company, Bebruary, 1953.

67 Ibid.

68 Mmployment Survey, 1941-1945. 
69 Interview with Bennett Teylor.

70 Fersonal interviow with $\mathrm{C}$. Lee Hammersla, Manager, Martins burg Branch, Wational Hruit Products Company, Nebruary, 1953.

71 Ib1a.

72 Telephone interview with WeIter Moyer, General Menager, O. H. Musselman and Company, February, 1953.

73 IbId.

74 IbId.

75 Interview with George $\mathrm{s}$. Young, after his roturn from the service 


\section{CHAPITER IV}

NEWTON D. BAKER HOSPIYAI

The most fermeaching wer activity to take place in Berkeley County, with the exception of the araft, was the location of one

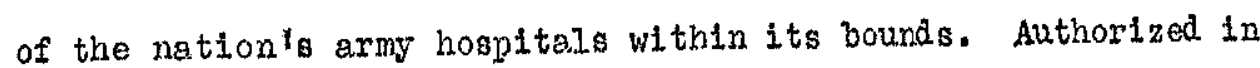
January, 1943, the site chosen was 186 acres of farm land southeast of Mertinsburg along Route tileven. ${ }^{1}$ The hospital wos named in honor of Newton D. Baker, Secretary of War during World War I, whose home and early lew practlce had been in Martinsburg. ${ }^{2}$

Builaing contracts were let in February, 1943, actlve construction began March 8, and on the 25th of March Colonel Brnest I. Oook arrived to assume command. Brectinis a temporary structure on whet was later to become the parade ground, he set up his headquerters, sup ly houses, and offices for the staff which he assembled within the next few montho. 3

Under the supervision of Major D. D. Ratt, Area Ingineer, the hospital began to take shape. Utilities were transported through a network of tunnels, ooon covered by the bullatng structures. By August, though the hospital. lecked interior finishing, quarters were opened for general duty personnel and plans were under way for the organization of the various clinics and departmente to be sot up Later.

Officers from the Surgeon General's office and Service Command Headquarters conduoted an officiel inspection tour on Jenuary 18 , 1944, and approved the hospitel, and on the $28 \mathrm{th}$ of thet month Newton D. Baker began to function actively as the first convoy of 169 
patients arrived from Ii all ox en General. Hospital in New York. 4

The dedication ceremonies wexe hold June 9, 1944. Colonel Gilbert Von B. Wilkes of the Crops of Engineers presented the hospitel to the Fifth Service Command and it wes accogted by the commanding officer, Colonel Cook. Among the guests of honor were Mrs. Newton D. Baker and her deughter, Mrs. John MoGeen. The 323rd Army Service Forces Bank gave an hour concert before the ceremony. Afterwerd, the great crowd of visitors remelned for severel hours touring the hoppital. 5

More then one hundred buildings had been completed at the time of the official opening, and construction continued thereafter with the adation of a gymasium and post theater. A networle of corridors integreted the hospital. These were inclined wherever necessary to avold the use of steps, so that a patient, even in a wheel chair, might make his wey to any part of the institution without going out of doors. The swimming pool was completed in the summer of 1945, and a landacaping program begun the first year provided surroundings of trees, shrubbery and grass for the bulldings. 6

During its first six months Newton D. Baker was a general hospitel in every sense of the word. It served as a debariketion point to which the wounded were brought directly from hospital ships in Newport News.

The work of the hogpital was carried out through its various services, a speclally trained staff member ot the head of each. A clearer ldea of the working of the hospital may be gained from a summary of these services. 
NURSING SHRVICE. A datachment of Army Nurse Corps members was stationed at the hospital. There wes, however, a universal scarclty of Army nurses. To alleviate this the United States Codet Nirse Corps was established for the training of potential Army nurses, and Nowton D. Baker was one of the flve general hospitols in the Iifth Service Command delegated as on instruction center for the Gadets. They were sent here for their finel six months of troining after two and one-half years in the schools of musing in Pennsylvania, MexyIand, Washington, D. C., and West Virginia. Here they received daily classes in Army procedure end methods, clinicel instruction in the wards, and military drill, the purpose being to enrich clinical prectice by actual experience with war casualties. of the first group of fifty-three Oedet Nurses who completed their treining at Newton D. Boker, two were married, two went Into the Naw Nurse Corps, two into veterang work, ten into civilian nursing, sixteen into post-graduate work, and twenty-one joined tize Array Nurse Oorps: Many other Dedets followed."

Resident volunteer nurses aides, nurses aides from the surrounding commities, and other volunteer assistants also helped make up the regular nurging deficiency. Extre hours and duties were taken on by the aldes from time to time.

RECONDIMIONING SHRVICE. This program wes introduced by the Army into its hospitals in 1944 in an effort to "Bridge the gap between acute 11lness and fully recovered strengti. 119 Its purpose was to readjust the patient mentally and physically for his return eitier to civilian life on to active duty. Both the educationel and 
the physical reconditionling sections planned prograins in conjunction with the treatments being carried on in other departments of the hospital.

Educationel Reconditioning Section. Through this of fico the United States Armed. Forces Ingtitute was publicized. For a twodollar enroliment fee the Institute sent textbooks and lessons to be mailed back as completed and were then graded and returned with comments. These correspondence courses, offered in narly every subjoot imaginable, could be taken for credit tovard a high school diploma or a college degree. Some patients and duty personnel fin1shed their high ochool work through the courses; others took them to prepere for future vocations. One patient, for example, who planned to open a hotel in Miani, took business management, as did another who hoped to establish a bakery. Building construction was also popular. If help was desired the Reconditioning offico arranged for a tutor. 10

A theater program wes begun in segtember, 1944. About thirty members of the drametics class, sponsored by the Red Cross under the Reconditioning Program, took weekly fleld trips to Washington and Baltimore whenever matinee tickets were available. As tickets usually were avallable, these men saw most of the major plays. After each they were taken backstage to talk with the actors and learn flrst-hand about stage settings, lighting and sound effects, and professional performances, 11

Among the patients at Newton D. Baker was Private Christian Warthoe, a noted gculptor, born in Denmark and a veteran of World War I. In an article in the post newspaper, Private Warthoe was quoted as saylng that sculpture could help a patient llorget himself 
when ise gets his fingers into the claym-keeping his mind and his hands occupied creatively. "12 Soon Wartioe was assigned by the Reconditioning Service to instruct a class in sculpture. He belleved that once a student is interest was flred he would want to vork, mentally and physiculiy, to express himself; and it was no doubt with deep satisfaction that he noted at the end of one day a man returning to the classroom for his crutches which he had forgotten. 19 Meny who had never thought of modeling before were not finding hours of enjoyment.

Beginning in May, 1945, the Reconditioning Service provided a series of lectures by industrlal experts who came to the hospital and discussed postwer employment opportunities with the patients. These telirs covered the automotive and automotive repair business, the steel industry, synthetic fibers, professlonal basebali, and various other topios: 14

A course in airplane mechanics was offered under the direction of Mr. Edward G. Parkinson, manager of the Mertinsburg Airport and head of the area Clvil Alr Patrol. Olagses were given In combustion engines, aircraft power plants, general repair and conditioning of planes, and later advanced classes of ered theory of flight. Observation trips were made frequently to the airport. ${ }^{15}$

Pbysical Reconditioning Section. The Physical Reconditioning officers were alded by six enlisted men, all college graduates in physical education. From elght to four-thirty olclock dally separate groups of advenced petients, other ambulatory and open ward neuropsychiatric patients, an average of 275 each day, met in the post gymnastum for clasges which included corrective exercises, games

and calis thenics. 16 
Typlcal eym class garb for many army hospitals ves a conglomeration of fatigues, pajamas, and the two-plece maroon corduroy outfits popularly known 2.8 "zoot-sults." It was felt by the Reconditioning Service thet unlformly outfitted classes would not only nake for a smarter appearence but would hlep each man fit more readily into the gy program. To overcome wartime shortages and atill provide uniforms, the ataff combined imagination with the materials at hand. Obtaining class "X" suntan trousers, those no longer suitable for regulation wear, they cut the legs off above the knees, bound the edges, and thus furnished each man with a poir of gym shorts. Rather than waste the $10 \mathrm{~g}$ ends, they attached loops to one end of each and stitched the other end shut. The bog thus formed would hold a complete gym outfit. On it was stencilled the number of the suit it contained and it was hung in the supply room on a hook tagged with that number. This system, substituted for the usual cage system, Bavod much valuable spoce in the gynasium. It was found that moccasins could be bought for less than the regular price of gym shoes, and were ordered by the gross in all sizes. In addition, a white T-shirt, wool socks and supporter were issued to oach patient. The outfits were turned in each weokend, collected by the post laundry and were washed and ready for use egatin on Monday. The appearance of these now uniformly outfitted gym clesses of more than 300 patients was partly responsible for the remark of Mafor General James I. Collins, Oommanding General of the Hifth Service Command, to Reconditioning Chief Major Peter $W$. Sweetser that "the Newton D. Boker physical reconditioning program is tops in the service connand and one of the best in the country, 117 
There were other foctors, too, behind this statement. The post athletic officor, First If ieutenant Morton Thompson, was assigned to b1s duties as chief of the Physical Reconditioning section in the Ta1.1 of 1944. Before entering the ervice he had recelved a Master of Arts Degree in physical education at Hew York University, after starring in bagketba11, track, swimming, ice hockey and tennis. ${ }^{18}$ once at Newton D. Baker he set about organizing an intensive sports program.

A softbell league had been formed during the summer, and the season ended with a banquet at which an honor plaque, made and lottered by the patients, was presented to the league chanpions. The winter sports program was now organized to include civilian and duty personn as well as patients. Two eight-tenm bowling leagues were organlzed, as was a hospital basketball tournament. Honor plaques wore owarded to all league champions, with the players names inscribed on each. 19

Basketball seemed by far the most populax sport. Dhring the winter of 1944 a Newton D. Raker squad wo orgenized and games were schedulea with outlying teams, Ashford Genernl Hospital, Waleman General, West Virginia University and others, Colonel Cook encouraged this more intensifled program, wishing to make his post the leader In the area. Transportation was made avallable to players, both milim tary and clvilian, who might now travel to and from games "on orders" by rail or government transportation. Worte in the departments kept most from leaving except over weekends, 20

A WAO team, called the Bakerettes, was formed, playing such surrounding teams as the Camp Detrick WACs and the girlo team at the Falrchild Aircraft Plant in Hagerstown, Maryland. 
The hospital tean by the end of the season had a record of twentythree wins and four losses. After winning the championship of District Number Five in the ifth Service Command competition, it finished second in the sexvice command. Finels by losine to Helrema General Hospital 30 to 23.21

The post eymnasium was utilized day and uight, with evening supervision by the special service athletic staff. Competition was keen among the convelescent potients in the weelily physical fitness tests, the varlous events including sit-ups, stroking with the rowIng machine, pedaling on the stationary bicycles, and gripping the hand grip mechine.

Other pleces of recnditioning equipment were added from time to time. With a device called the wrist circumductor a patient, his forearm atrapped to a block, could strengthen on injured wrist by revolving a wheel just within reach of his fingertips. ${ }^{22}$ some reconditionlng classes were talught by civilitens; others by Army men and women. Many of the tools and machines vod in the classes vere made possible by civilions. Many tired minds ond weakened muscles vere strenethened and coordinated as patients became interested in radio repaix, shop work and welding, typing, design, photography, press work and typesetting, and the varlous kinds of art which could be done even in bed. 23

Badminton was introduced into the reconditioning progrem in answer to the need for an activity for convelescents who could not take port in major sports because of les injuries or the 10se of an arm. The eymnasium was also equipped for welght lifting, volley bol1, shuffleboard, handba11, and boxing. With the coming of spring, 
the sortball and voljeytoll. leagues wele expanded to include nore patients as woll as the WACs, murses, civilians and later fine prisoners of war wo arifived at tie post. The tennis courts and athletto fleld were completed, and arremgments made for uging the facilities proviced at the minicipal. golf course. 24 On August 9,1945 , the poot swiniting pool was offichally opened with swiming exhibitions, both sertous cond conic, and beauty contest at which Miss Newton D. Paher was selected from emong the $W A C$ and nurge contestants. Regularly scheduled sviming cladses were held from that time on. 25

In October of the same year, lifewton D. Baker Hospital was host to a training conference of fifty nedical officers who, having completed their internghip, were being treined to become chiefs of reconditionlng in regionel, generel and convalescent hospltels throughout the country. Meeting in calsses, they worked out detailed reconditioning sohedules then toured the hospltal to see the complex program in action. Novies taken on the post and open forum discussions rounded out the training. One principal reason Newton D. Baker wos chogen for this conference was that its program had functioned smoothly and was contimuing to do so in spite of the loss of numerous personnel and the increasing number of separations now that the war had endea. 26

MEDICAI SFRVICW. Al though obviously important in any hospital, the medical center at Newton D. Baker was apportioned a fewer number of beds than any other such service. There were two reasons for this. I'irst, the great strides that have been nade in the development of modern medicine together with silfa, penicilin and other drugs, have prevented the spread of epidemics which were prevalent 
In other wars. Mojor General James I. Oollins, commanding generul of the Fifth Service Command, said at one time, "We have yet to lose a soldier from cholera or typhoid feverl and that the misitary death rate from disewse had decreased to one twenty-fifth of that of 1918.2 ? Many cases did arise, however, of molaria, gastroin-testinal, cardiovascular and other traumatic conditions and these vere treated competently.

To further account for the relatively amall medicol service was the fect that Nevton D. Baler in August, 1944, wes changed. from a general hospltel to a specialized center in neurosurgery, plastic and eye surcery, neurology, and open and closed ward neuropsychlatry. The hospital was thus no longer a deportation center only; it also recelved these particular types of cases from other hospitels. 28 WEUROPSXCHIATRIC SERVICE. At first a section of the Wedical Service, this department came into its own upon belns designeted as one of the Newton D. Buker specialties, and mucin pioneer work was done in it here. Group therapy was one of the forms of treatment introduced. A psychiatric patient was treated not as on outcast but as one who had contrected a curable diseese, and this attitude in Itself aided in the rapid recovery of a great many patients.

Neurology section. This was an integrel part of the neuropsychiatric service and Its staff worked in close conjunction with the specialists of the neurosurgery section to be alscusged later. Iate in 1944 an electro encephalogram unit, set up and operated by specially trained personnel, provided electric brain treatments for those in need of them; wille on aphasia clinic served patients whose powers of speech had been impaired or lost entirely. 29 
occupationl theripy, the work of which has been reviewed above, played a vital. part in the reorlenting of neuropsychiatric patients. The great majorlty of cases were found to respond qulckly to a progran of physical exfrcise, work with hobbles, reading, doncing and other forms of recrestion with constant emphasis on normelcy.

DENTAI SERVICE. In adaltion to routine cleaning, filling and generel repair vork for some tiree thougand patients, the dentel clinic alsid ald plestic surgery. One of the great achievements of the hospitel wes the work done by the dental service in mexillofactal surgery-the replaclng of misging javs. Other parts of the body were also replaced through prostheses and skin grafts. 30

X-RAY SFRVICE. ThIs was organized and in constant use from the arrival of the first patients to the hospital. Other services, particularly the surglcel, depended heavily upon it.

PHAFHACY. Anotier section whtch was made independent of the medical service upon reorganlation, the phormacy was completely stocked at a.l times end served the ent1re hospltal. It was maned day and night by a staff ready to fill prescriptions directli as they were gent down from the Army doctors.

DISFEISARY STRVICE. This center was maintained to serve the general duty personnel of the hospltal as well. as veterans and prisoners of war.

SURCICAI SERVICA. When Newton D. Baker was made a speciallaed hospital with the emphasis placed upon surgery, only a small amount of reorganization was necessary due to the fact that the operating roons and equipment $h_{k} d$ originally been set up in anticipation of a heavy demund on the surgicel aervice. 
Genergl Surgery Section. Because of the preponderance of work in other sections this remained smell in cormarison. Its extreme importance, however, is obvious.

Orthopedic Section. Although not one of the hospitel's designated specialties, orthopedic work was greatly in demand. The traction wards were usually full, so meny of them being cases of hand surgery that the hospital became a recognized center for this . type of work. Another large group of orthopedic patients were those who were having work done in connection with plastic or neurosurgery. 31

In a fully equipped orthopedic shop maintained near the warehouses to the rear of the hospital, eight enlisted men, working under the direction of the chief of the orthopedic service, mafactured the braces, belts, collars, special orthopedic shoes, and other mechanical. aids which were prescribed for these patients. Work was done on an individual rather than a production line besis, with each man taking the measurements of hig patient, making the appliance and then adjusting it to him personally. 32

Plastic Surgery Section. Thuring the war years plastic surgery developed from "largely a natter of cosmetics concern" 33 to a highly skilied and technicel science whtch, in rebullding and restoring missing or damaged parts of a wounded man, not only reactivated him as a person but did a great deal toward restoring his prewar persona.1.1.ty:

Neurosurgery Section. Neurosurgery, the largest single seotion of the hospital, was the outstanding spectalty of Newton D. Balcer. To a oldier one of the most appalling injurles is severance of the spinal cord. In world War I this meant almost certain death, or at 
beat, hopeless parelyzation. But of the stxty-nine at liewton $D$, Balcer in the spring of 1945 who had sustained this injury, fortythree were walking. Oredit for thls major medical triumph goes primaxily to the sulfa drugs ond penteilil for reducing infection of the bladder and kidneys, the main single cause of death in such coses. Fven more remerkeble was the work done in restoring these men to nearly normel lives, Though medicel sclence has not yet found a. way

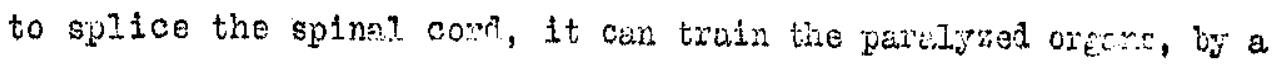
slo\%, vedious process, to function antomatically. Then, with the aid of crutches and steel braces, the patient undertakes the most difficult tagk of all--learning to walk. Two things are inuortant here: the patient must be convinced of the fact, hovever Incredible that it will be possible to walk; and he must, through spectal exerm cises, strengthen the arm and shoulder muscles which enable nim to swing his legs. The finel step in the process is training the patient for work which he can do with his head and hands. The following case, reprinted from MIme Magazine in a June, 1945 issue of the post newspaper, is typical of many which were brought into the spinal ward.

One of the first to wolk in Hard 108 was Pfc. Harry Sanders, $24, \ldots$ hurt at Saint Io last sumer when a bomb exploded five feet bohind him. Almost completely paralyzed. from the wist down, blue-eyed Private Sanders vent home to Marysvilie, Pennsylvanta, on furlough last month, hopped proudly around the house on his braces; laid plans to return to civilian life as a radio mechanic. 34

Eve, 殒x, Nose and Throat Section. Mis department wos constantly in use though its patients had come to the hospltal primar11y for other types of treatment. The Hye Section grew in importance when specialists were sent in to provide the surgery needed in repairing eye sockets, while another group of highly skilled tecinicians specialjzed in making plastic prosthetic eyes. 35 
The Central Service, which housed all surficrl. supplies, and the Physical therapy as vell as the Anesthesia and Operatingmoom Sections were also maintained through the Surgicn service. In addition, the Surgical service sponsored many conferences and prom fessional meetimes of both Army and civilian nedical specialists which were held at the hospital. 36 The worls done in surgery at Newton D. Baker was a vital contribution to the medical profession and to humanity.

SPECIAI SERVICES. The ovowed purpose of the Speciel Services Department was to give everyone on the post "something to do, something to see, someplace to goll every waking minute. ${ }^{37}$ First Ileutenant Morton Thompson aid. excellent work in organizing teem activities and bringlng in events from outlying towns. It became the job of Second Iieutenant W1Iliam Rintonl to direct the arranging of 011 other forms of entertaimment-mances, bringing in celebrities, and plonning the film schedule ot the post theoter. 38

The task of these men was made eesier through the unfaling cooperation of the Red Cross and thet of various other groups and individuals in the surrounding commities. For exemple, during the winter of 1944, Billy Blake, Chalrman of the Washington, D. C. Boxing Commission, brought eighteen men, members of the Apollo Athletlc Olub of Washington, for nine boxing bouts in the post symnasiun. This was the second fight program for patients; others folloved, including one featuring lady wrestlers, and all were broadoast to bedridden patients over the public address system. 39

The new recreation center, complete with four bowling alleys and five pool tables, was formaliy dedicated on Fr1dey, March 16, 1945 , 
Witi spenches by Deputy Surgeon General Mejor General G. S. Iull, and Colonel Cook. An exhibition of bowling was presented during the eventing the vorld's doubles champlon, Buddy Bomer; then followed a series of bowling hatches climaxed by one in whtch General Iull defeated. Colonel Cook by two points. 40

In Auril of thest year a capacity crovd of men from wewton D. Baker and other amy posts nearby saw a practice baseball game between the Philadelphia Athlotics and Toronto at the Hagerstown, Maryland, Bell park as guests of the Martinsburg lions dub and the Hegerstown Junior Board of Trade. ${ }^{41}$ The recreation directon at Fairch1ld Aircraft in Hagerstown had brought inis Maryland Giris: Basketball Champions, alvided into two teams, for an exhibition game in tice mansium the winter before. 42 The World Series of 1945 was broadcest in the hospitil on a direct line from radio station WJWJ in Hagerstown. This service was given by Wrs, Olara H. Hachter of Hogeistown, to whom after the final game colonel coor presented a scroll signed by nearly a thousand patients in apprectation of her thoughtfulness. 43

A sertes of aightseeing trips to Washington, each covering a different route in the city, was offered in the summer of 1945 . This proved so popular that it was repeated. 44 Also during that summer, patients were invited, by arcingement of Lieutenant Thomuson with Mr. Olark Griffith, owner of Griffith Stadium, to attend home ganes of the Washington Senators. Throughout the geuson twenty-five to fifty patients a week, accompanied by Red Crosa recreation workers, traveled to Waghington to see the games. 45

Because its location is not on the beaten track of the professional entertainers, visits from the stars were not ordinery occurrences 
in Nevton D. Baker as at hospitals in the metropolitan arens. To patients and staff alike, those were red letter days when tallulah Baikhead dropped in while playing in Washington and when Walter Pidgeon and signe Hesso made similar calls. 46 on one occasion the Roy Eldridge Band stopped en route from Washington to Hagerstown and entertained in the recreation hall for two and a half hours. 47 one of the biggest events was the program arranged by the Specitil Services Office in cooperation with the Coca-Cola Bottling Works, sponsors of the Shep Fields radio show, the "Victory Parade of Spotilght Bando." It was held Thurgdiny night, November 9, 1944, and twonty-five minutes of the program was broadcast from the hospltal over the Blue Network. A record crowd danced and listened in the post gymnasium. This was the first time during the war that a radio station or big name band rendered a musical salute to the men of a reconditionine battalion. 48

Because performances such as these were relatively fow and fur between, those connected with the hospital pooled their telents and brought out a masical all-soldier review put together by the pattents with the help of the Red Cross, the WAC contingent and others and rehearsed between work hours. The new show was called "About Face." For it the men wrote their own songs and skits dealing satirically with physioal examinations, soldier routine, private lives of army cooks, berracks Iife, the privacy of a private, and evon a satire on the hardships of civilion existence. After the opening performance 1. went on tour of the communities in the vicintty of Martingbure and was well received. The net proceeds from the show went to the war fund. 49 
FOSPITAI YROCEDURA. By the end of the first yenr most of the rough apots in hospital organization had been ironed out, deportments streamlined and a system worked out to facilitate reaching the hospltal's goal of "the greatest amount of help in the least amount of time. 150 At 1ts peok, early in 1945, the 2ospitel contained about 3500 patients and thirty to thirty-five operations were being performed a day. Wille some patients were being seperated, others vere being flown in or were arriving dally on hospital trains, On one duy two trains of three hundred patients each were received. 51

As each group of wounded soldiers arrived tiney were screened and dispatched through the Central Dispensery to the surgical, medicel and neuropsychiatric services. Consultations were held with these services and their various branches (outlined above) and, if necessary, immediate medical treatment was given by army doctors. Inmediately following these consultations the patient wos given clean clothes and freshly prepared food, and the staff of telephone operatiors stood by to ploce calle anywhere in the United States so that he might notify his femily of his axrival. Portable ward telephones were availablo to bed petients. Hach new patient received a pamphlet entitled "HI Soldiex I", which Introduced him to the various hospltal services. At the post exchange, barber shop and Red Cross room he now found the small but importont luxury items which for most of the wounded had been unottainable for so long. 52

The followirt morning the new patient met with other new ambulatory patients in the post library to hear a welcome address and an oxientation talk by the commanding offlcer or the pergonal affairs director. Then with his overseas records assembled he was given a 
series of interviews during which a representative of exch of the hospital departments, grouped together in assembly-line fashion, gathered the information needed for work with that patient. In the processing line were the Army Air Forces or Army Ground Forces Ifaison officer, chaplains of all fatths, representatives from the milltary persomel section, the finence department, the detachment of patients to which he now belonged, the personal affairs officer, the legal adviser, the public relations officer and the reconditionfing service. The hospital by now knew the history of ench patient and the patient had at the same time lenrned the number of service ribbons and decorations coming to him, as well as the enount aue him in back poy, the time of services in the post chapel, his legel status, and vorious other items. A program of physical and educa- . tione.j. therapy was sot up for him by the reconditioning service in koeping with his plysical handicaps, end a press relekse with o. few remerks about his arrival wes propared by the public relations offic for his home town newspaper. Becouse of this system of rapld processing it was possible to completely laentify a petient and give him an idee of his immediate hospltel future within twenty-four hours, and to send him home on furjough with his back poy in his picket four deys to a week after his admltance. For bed patients unable

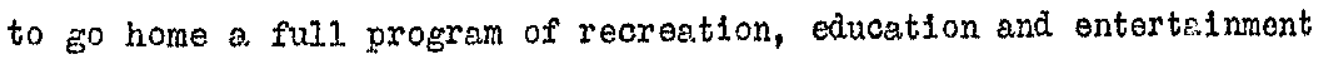
wos available, and for these men also a special guest house was maintained on the post, furnishing comfortable quarters to which relatives and friends wight come on visits. 53

WOMEN'S ARIN CORPS. The WAC contingent stetions at the hospital was known as the 20 th WAO Hospital Company. It comprised about one hundred women. The 106th, a second company of about a 
hundred more WACs vas activeted at Thewton D. Baker on July 13, 1945. Anong the latter eroup were those who, having finished basic troinIng at Fort Oglethorye, Georgia, were sent lere for a stx-weeks courso in medicel, sureicel or clertcal trining: Each Wa, upon completicn of the course, recoived a Tw 5 rating. 54

Becuuse their training was borough there were WaCo qualifieit to work in neerly every section of the hospltal. In the occupational therapy warda they helped the fatients who were learning hanicrafts. In the laboratory they did all types of analyticol work, rotating jobs so that each might gain a good general background. An 1ndication of their interest in their work was shown by the fect that some planned to go to modical. school after the war. WACs operated the hydro-therapy, thermo-therapy and electro-therapy machines in the Physio-Therapy Department. In the Eye Section two of the more artistic women helped mold and point artificial eyes. Wight others were on cell doy and night in the Iransportation section, revidy to drlye anythine from bus to ambulence. In Centrel services they aterilized instruments and stocked carts with medicines and supplies. Some helped in the Publice,tions Section, the post offlce, the diet Kitchens, the Finance Section and the Record Department, while others worked in the operating rooms, dental clinic, X-Ray section and at the information degtr. 55

For off-duty hours their quarters contained a day room with a snack bar, a reading room, and an outfitted writing room, while nearby was their own archery range and volleyball court. Special service functions also frequentiy included basketball games and other competitions bringing together women soldiers from Newton D. Baker, Carnp Detrick and other neerby arny posts. 56 
PRISONERS OF WAR. During the latter months of the war, through cooperation of the hospital officials with the West Virginia iortim cul ture Society, 175 to 200 Germon prisoners of war vere sent to Newton D. Baker from Ashford Generel Hospltal at thite Sulphur Springs. Housed in former Civilian Conservation Corps barracks secured from neor Hikins and set up on the hospltal ground, these men were avallable to $100 \mathrm{l}$ orcherdists at the prevalling wage rate to help the 1.945 apple crop. 57 The prisoners were included in the Special Services program and were even offered a series of lectures In German on the subject of American Government and Democracy by Patient Frivite Alfred. Heinice. Private Helnke reported that they seemed interested and asked intelligent questions. 58

That Niewton D. Baker became a leading economic factor in Berkeley County and the surrounding aree, is indicated by an enployment survey made by the Martinsburg Chamber of Comnerce and showing that by 1945 a total of 1350 civillans were on the hospital payroll,

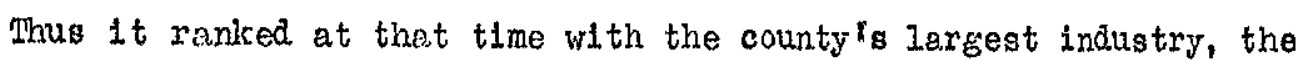
Interwoven Stocking Company, which had 1365 employees. Hroloyment at the hospital reached a peak of 1400 in $1946 \%$, then aropped to 250 that same year as the influx of pattents diminished. In 1947 when the army withdrev and the hospltal was made a veterans administration center, the numbor of workers levelled off to around 750 and the center apparentiy wi1]. continue to be one of the principal sources of employment in the county. 59

An indication of the competent manner in which the hospital rendered its vital services mey be seen in the following quotation from the citation which accompanted the Meritorlous Service Untt 
Plaque, awarded the Headquarters Section, 3594 th Service Command

Unit, Wewton D. Baker General Hospital, by command of Major General

Collins of the Fifth Service Oommand:

This unit has echieved and meintained a high standard of disclpline, morale and performance of duty, as evidenced by superior militery courtesy; appearence of personnel. installations and equipment; and a minimum of trials by courts mortial end punishments under Ail 104, venereal disease and absence without leave.

The loyal cooperation displayed and high standaxd of performance maintained by the members of this command, in meeting the emergencies created by large numbers of returning vounded soldiers, reflect the highest credit on thelr unit and the rilitary service. 60

\section{SUMMARY}

In concluding this study of Berkeley County in Forld War II, note should be made of several major trende of both economic and social significance which developed during the war years and were peculiar to this county.

In an econonic sense the war brought about a profound change in Berkeley County. The cost of Iiving which had Increased 16 per cent throughout the country in 1942 and was expected to go up 50 per cent in the next year 61 wes felt here as elsowhere. With it, however, purchesing power also increased-due in this area to employment at the Feirchild Airoraft Plant in Hegergtown, Maryland, overtime at the railroads and quarries, work at Newton D. Beker Hosp1tal, and a generally higher wage scale in other industries. Independent businessmen from merchants to landlords made good money. The year 1943 saw in the county a small boom which expanded into an all-time high by 1946.

The prosperity of the industriol. workers surpassed thet of many salaried professional poople, the so-called white-collar group, with 
the result that some in this classlfication left their posts to go into industry.

The effect of World War II upon fermine, the principel occupation of the county, was paradoxtcal. Shortages of manpower and materiels mede it seem at times a.lmost imposstble for some furmers to remein in production. Yet at the end of the war forming omered a. me.jor, mechanized industry with rural electrification, new tractom corn pickers, mijking machines and farm homes in good repair. Three major fects had brought this about: First, the general prosperity vitin the United States and shortages abrod had provided better merkets than hod existed since the $1920 \mathrm{ls}$. Second, mechanization of farms; while fewer unskilled "hired hands" vere avaliable for farm work, fewer were needed. Most heavy worls could now be done by machines. The third fact was the introduction of scientific nethods, includine proper diet for farm animals, new sproys, the use of insecticides in the barn and incressed attention to fertilizers.

Thus, while the war brought anxiety, sorrow end irreplacable losses to many fomilies, it also brought a demree of progress to a relatively stetic community. In the form of good wages more money than ever before flowed into e county where according to lone standing tradition it was fashioneble to be poor. New homes were made possible by this increased. wealth and, as they became available, suon modern appliances as television, dishwashers and home freezers in greater numbers than could have been expected normally.

Soclally, the Iocation of Nevton D. Baker Fospitel within tie county had the effect of strengthening a apirit of communty cooperation. That the people felt a responsibility towerd the hospttal 
petients is seen in the two Uso centers and verious smaller projects by groups and individurls to provide a messure of comfret and entertalnment for the wounded veterans. Mach of the Red Cross activity centered round hospltal needs. The coopere.tive effort manifested in these activities prepered the way for future communty undertakInge, notably the Berkeley County Wer Memorlal Pork of which the people of the county could be justiy proud. 
FOOMYOTSS

CHAPIER IV

I Telephone interview with Mr. Frenk Olophem, whose ferm was included in this land, November 1]. 2952.

2 H. I. Alexender, A Short History of the Lete Ionorable Hewton D.
Bel:er.

3 Personal. interview vith Colonel E. I. Cook, Oomnending Officer, Jevton D. Buker General Iospital, June, 1946.

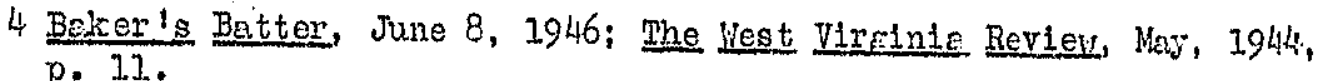

5 Ibid.; other speokers at the dedication vere Nojor Coneral Norman T. Kirk, Surgeon Ceneral of the Arny, Major Generel James I. Collins, and formei Governor John J. Cornwell.

6 Ibja.

7 Interview with Colonel cook, June, 1946.

8 Bakerlo Batter, Apri1 14, 1945, August 25, 1945.

9 Ibid., June 8, 1946.

10 Ibid., March, 1945.

11 Ibid., September 30, 1944, October 15, 1944.

12 Ibia., Junẽ2, 1944.

13 Ibid:, October 15, 1944.

14 Ibid., May 12, June 9, August 4, 1945.

15 Ibia. , August 25, 1945.

16 Ibid., April 21, 1945.

17 Ibid.

18 Ibid., November $15,1944$.

19 Ibid., November 15, February, 1945.

20 Ibia., October 15, 1944.

21 Ibja., March, 1945. 
22 Ibia., June 23, 1945.

23 Ibla., July 14, 1945.

24 Ib1d., Nay 12, 1945.

25 Ibid., August 11, 1945.

26 Ib1d. , October 13, 1945.

27 Ibid., June 21, 1944.

28 Ibian, June 8, 1946.

29 Ibid.

30 Ibid.

31. Ibia.

32 Ibid., September 15, 1945.

33 Ib1d., June 8, 1946.

34 Ibla. , June 16, 1945, June 8, 1946.

35 Ibid. , August 11, 1945, June 8, 1940.

36 Ibid. June 8, 1946.

37 Ibid., April 28, 1945.

38 Ibid.

39 Ibic., September 30, Hovember 15, 1944, April 28, 1945.

40 IbIa., March, 1945.

41. Ibjd., April 14, 1945.

42 Ibid., October 15, 1944.

43 Ibid., October 6, October 20, 1945.

44 Ibja., Ju1y 28, 1945.

45 Ib1d., May 12, 1945.

46 Ibid., March, 1945.

47 Ibia., October 15, 1945.

48 Ibia., November 15, 1944. 
49 Ibid., March, 1945, Apxi1. 14, 1945.

50 Ibia.. July 7, 1945.

51. Interview with Colonel Cook.

52 Baker 's Batter, July 7, 1945.

53 Ibid.

54 Ib1d., May 26, July 7, 14, 1945.

55 Ibia.., May 26, July 14, 1945.

56 Ibid, Febmary, 1945.

57 Personal interview wi.th $C$. W. Wood, member of Horticulture Society committee on securing prisoners.

58 Baker's Batter, September 8, 1945.

59 Tmployment Survey, Martinsburg and Berkeley Oounty, November 1 , 1945 to April 1, 1947, Mertinsburg Chamber of Lomerce.

60 Baker's Batter, September 8, 194.5.

61 General. Maximum price Regulation, OCD Hiles, Var History Commiasion Records, West Virginia University Iibrary, Morgantown. 
APPEXDIX I

MILITARY 
ARM

HONOR IIST OF WORLD WAR II CASUAITIES*

BIRKELEY COUNTY

Neme

Alessio, Trank Anderson, Joomard $M$. * Atringon, poter W. Atilinson, Robert $b_{\text {. }}$. *** Bas gy, Georse $\mathrm{R}$. Barrett, Ralph Beard, Phllip I. Bovey, Bruce D. Boyd, Haul. $\mathrm{E}$. Brichnex, Albert I. Busey, Trederıck M. Butis, Bernard W. Butts, EMoxy T. Chepmin, Falph W. **aclork, Alex $\mathrm{Va}$ Cox, Walter A., Jx. Devis, Nevton B., Jr. Degrange, Ceorge W. Dedrick, Rayncina $c$. **Devers, Hasu M. Dunham, Herman Jr. Duva17, CharIes $\mathbb{N}$. Foster, James $\dot{A}$. Fowler, Peul D. * * Jenks, Charjes W. Garrett, Paul 0. Gatrell, John D. Gish, Leonasd it. Grogory, Willis D., Jr: Grey, Roger A. * * Griffith, James Grove, Robert I. ** Groves, Doneld H. Guthrie, Robert W. D. Harrison, Ernest $I$. Henderson, Williem $B$. Herrell, Grover V. Hitckman, William $\mathrm{K}$. Hillierd, Freddie E. Hinton, Guy $G$. Horner, Forest $\mathbb{D}$. *** Hovermale, Price 0 . Joyce, James $\mathrm{T}$.

\section{Grode}

$$
\text { Sint! }
$$

Alir Oadet

Ii eut.

Oapt.

Opl.

PfC.

Pvt.

iilisht ofc.

Fvi.

Set.

Evt.

Pfe.

Pvt.

Pvt.

T. Sgt.

Pfo.

1-Iieut.

TI. Ofc.

S. Sgt.

Maj.

Fvt.

Pvi.

Pfe.

Pvt.

pvt.

Maj.

2-ijeu.t.

S. SEt.

SEt.

Pvt.

Tec. 5

Pfc.

Opl.

I-Iieut.

Pvt.

Pfe.

Pvt.

pot.

Pfo.

Pfe.

PfC.

s. Sgt.

Pfo. lianner

of Death**

INIA

DNB

DARB

KIA

DNB

KIA

KIA

DNAB

- KIA

DER

ISIA

KIA

DOW

IIA

KIA

DOI

KIA

DIB

KIA

DNB

KIA

IIIA

DOW

KIA

ZIA

ZIA

KIA

XIA

IIA

KIA

KIA

DNB

KIA

DOW

KIA

KIA

IIA

KIA

IIIA

KIA

SOD

IIIA

KIA 
Jame

Grade

Manner

of Death

Kearns, William I.

Prc.

KIA

Keedy, Bernard

Zoes, Harlan $\mathrm{x}$.

Kelly, Don P.

IeMaster, Ross $C$.

Lewis, Bernard $P$.

Lorraine, Edward $N$.

Iuttrell, Bruce $\%$.

May, Ellsworth $B$.

Mclauley, Paul C.

Mcilaniel, Vernon $\mathrm{C}$.

Pvt.

KIA

S. SEt. IIA

Pfc. KIA

Pvt. KIA

Pvt. WIA

S. Sgt. KIA

Pvt. DIIB

PfC. DOH

Pfo. KIA

Fvt. $\quad$ KIA

Mciree, Douglas P.

1-Ijout. KIA

Milier, Albert I.

Pvt.

KIA

Miller, Gien A.

Mil.Is, Robert $A$.

Morgen, Melvin 0 .

Myers, Robert I.

Norris, John Jr.

*** Oates, Roy J.

Pine, George $b$.

Racey, Blaine 15 .

Richerdson, Joseph W.

Rickel, Thomas $J$.

Riley, Semuel M.

Rogers, Delmont T.

Rogers, Hobart $\mathrm{t}$.

Smlth, 01 arence $W$.

Smith, Woodrow W.

Snapp, Charles B.

Spiker, Delmont $M$.

Stanley, Harold I.

Stanley, Julian N.

Stewart, John A.

* * Tabb, George E.

Thomas, Howard $\mathrm{T}$.

Thompson, Robert Jr.

Tiristan, Elwood I.

Wasson, Taylor $\mathrm{E}$.

Weaver, Robert $M$.

Welo.man, Donald j.

S. Sgt. KIA

Tec. 5 KIA

PVt. KIA

S. Sgt. IITB

Svt. $\quad$ DNB

Pfe. KIA

T. Sgt. DINB

PfC. IIIA

Cpl. DOW

s. Sgt. DON

s. Sgt. IIIA

Pvt. IIA

Sigt, IIA

Tec. 5 IIA

Sgt. DOW

Capt. DNB

Sgt. KIA

Opl. DIB

Sgt. KIA

1-Ii eut. KIA

Pvt. KIA

Pfc. KIA

S. Sgt. DNB

PfC. DOW

Pfc. $\quad$ KIA

Pvt. IIA

Pvt. KIA

PfC. KIA

S. SEt. IIA

$\begin{array}{lll}\text { Wright, James } N_{0} & \text { S. SEt. } & \text { KIA } \\ \text { Young, Allen } D . & \text { Tec. } 5 & \text { KIA }\end{array}$

Young, Cherles S.

* Honor Iist of World. War II Dead and Miasing, State of Weat

Virginia, Depertment of War, June, 1946.

* DOW DLed of Wounds

DOI Died of Injuries

DNB Died Non-battle

TOD Finding of Death

RIA Killed in Action

** Native sons not on official list. Mertinsburg Journal files. 
MAVY AMD MARINES

IFONOR IIST OF WORLD WAR II CASUALTIES*

BTREXYIST COUNTYY

Jane

Athey, George Thoinas, Jx. Gaver, IIenry Clayton Janes, Guy W.

Knox, Thomas Moore

* Martin, Charlea H.

Mason, Iyle Juntor

Miles, Williom Francis

Milis, OIifford

Minnich, Valter I.

Morgan, James HoIland

Morrow, Joseph Gardner

Myers, William Thomas

* *Ross1, Carlo

**Smith, Harold $\mathrm{T}$.

White, Kenneth I.

\section{Grade}

Fireman 2c

Ens.

Pfe.

Mis

Pvt.

Coxn.

QM 2c

Seamen IC

Pvt.

Pvt.

Bins.

Coxn.

A. S.

Mo. M.M.

Pro.
Brench of Manner

Service of Death

$\begin{array}{ll}\text { Navy } & \text { KIA } \\ \text { Navy } & \text { KIA } \\ \text { Marine } & \text { KIA } \\ \text { Javy } & \\ \text { Marine } & \text { KIA } \\ \text { Navy } & \text { KIA } \\ \text { Navy } & \text { DNB } \\ \text { Nevy } & \text { DNB } \\ \text { Marine } & \text { KIA } \\ \text { Marine } & \\ \text { Navy } & \\ \text { Navy } & \text { TOD } \\ \text { Navy } & \text { DNB } \\ \text { Navy } & \text { DOI } \\ \text { Marine } & \text { DOH }\end{array}$

* Honor Iist of Worjd War II Dead and Missing, State of Hest Virginia, Department of Var, June, 1946. ** Natire Sons not on official list. Martinsbure Journal files. 
LIST OF WOMTIN IN SERVIOE

BERKRLISTY COUITYY

Hame

Aikens, Tiny $J$.

Alexender, Elennor $\mathrm{g}$.

Anders on, Lilia $\mathrm{F}$.

Beard, Iililian $B$.

Blasingrane, Freda V.

Boltz, Florence II.

Bowers, Jessie

Bower's, Wanda I.

Brenner, Holen 0 .

Brichner, Margaret $C$.

Brown, Ella I.

Browne, Hazel.

Busey, Hauny $\mathbb{E}$.

Campbell, Mary S.

Campion, Katherine G.

Cariton, Thelme. I.

Chaffee, Ruth D.

Chapman, Velma J.

Qlendining, Anne $\mathrm{I}$.

Olendening, Mary I.

Crowell, Altce $M$.

Ditlow, Ruth

Donato, Rosalia M.

Dupre, Catherine V.

Durburaw, Jean

Havey, Marguerite 0 .

Whwards, Ruth G.

Eiliot, Mildred I.

Feulkwell, Elsie D.

Erench, Wilda I.

Fullmer, Marilayne Is.

Bunkhouser, Bdith B.

Gasper, Alvia Vicic

Gineras, Doris B.

Gray, Freda P.

Grove, Frede $\mathrm{H}$.

Grove, Pegey

Grove, Perry $\mathrm{T}$.

Gum, Evelyn

Hayes, Wilda I.

Haynes, Betty G.

Hedges, Helen I.

Hendry, Hel on $\%$.
Branch of

\section{Service}

Navy

Army

Army

Army

Aing

Army

Arrny

Nevy

Army

Novy

Army

Army

Navy

Army Nurse Cosps

Aung

Army

Army

Army

Army

livy Nurse Corps

Army

AlTC

Army

Army

Navy

Army

Army

Marine

Army

Arruy

Navy

ArTO

Army

Navy

IIIC

NDSO

InIO

Army

Army

Army

* West Virginia Selective Service Headquarters, Charleston, supplemented by Discharge Records, Berkeley County Clerk's Office, and Martinsburg News files. 
IIST OF WOMEN IN SHRVICE

IIame

Henshaw, Ioulise

Herber't, Mergaret $i$.

Hoffmaster, Lavetto. $G$.

Hook, Hizaboth

Horner, Lennie A. M.

Hul1, Ruth II.

Keedy, Iillitian C.

Keplinger, Estella I.

Kettering, Detty Jane

Kitchen, NiIma N.

Lake, Thelma I.

Leonard., Rosemery

MoAIIister, Eleanor 0. MeOarthy, Merjorie B.

Moterren, Gladys R.

Martell, Norme S.

Martin, Nende i.

Miller, Alberta

Miller, Anne M.

Miller, Elizabeth

Morrow, Louise Tebler

Norrow, Sylvia T. S.

Noll, Beverly $\mathrm{E}$.

No11, Helen

0IIverio, Catherne Ann

Osbourne, Hieanor

Pfarr, Frances $B$.

Pitman, VIrginta B.

Pleth, Dorothy

Reaves, Loulse $\mathrm{H}$.

Richards, tidne

Rjelsetts, Mary B.

Ryan, Ruby Virginia

Schuman, Joyce M.

Showers, Mary Jane

Snel1, Kathleen s.

Somers, Lennie A. M.

Stephens, Helen

Stevens, Bettie I.

Stewert, Pegez G.

Stewart, Mebel. 0 .

Stilwel1, Mary I.

Stotlemyer, Mary $\mathbb{E}$.

Tambascia, Helen D.

Tonry, Ruth R.

Triges, Rebecca J.

Turner, Frances
Branch of

Service

Navy

ANC

Army

Army

Nevy

INevy

Navy

Havy

Army

AirC

Army

Marine

Army

Marine

Arny

Navy

Navy

Army

Army

InC

NHO

into

Army

Army

Army

Mevy

NiTC

Nevy

Navy

Navy

Nisvy

Army

AnI

Arny

Army

Navy

Navy

Navy

Army

ANO 
IIST ON WOMEN IN SEHPTCE

Name

Vermilvea, sara $M$. Welty, Agnes I. Welty, Catherine Whitacre, Virginia Yenalatus, Violet $M$. Yost, Iillian I. Zaherie, Futh $\mathbb{N}$. Zombro, Norma $\mathrm{E}$. Zombro, Rachel $\mathrm{K}$.
Brancin of Service

Navy

MIC

Au'my

Army

ANC

Hevy

Navy 
PURESE HEEART*

\begin{tabular}{|c|c|}
\hline Adams, George & Dovis, Abner H. \\
\hline Aikens, George D. & Dean, Benfamin \\
\hline Al1 en, Stockton 1 . & Dellaven, Virgil A. \\
\hline Armstrong, Doneld & Ditlow, John 0. \\
\hline Ashby, Howard & Duf̂].inger, John \\
\hline Atkins, John $B$ & Dunhem, Robert \\
\hline Barrow, Hobert & Duvall, Claxence F. \\
\hline Banks, Robert $I$. & Edwerds, Earnest I. \\
\hline Beel1, Fh1llip D. & Edwards, Roy I. \\
\hline Bogers, Homer S. & Everhart, Harry $D$. \\
\hline Bowers, Cecil & Feircloth, John $\mathrm{E}$. \\
\hline Boya, Devia Fi: & aulkwell, James $W$. \\
\hline Burkhart, Glyde V. & Flles, Wallece I. \\
\hline Butts, James $W$. & Franks, Clyde B. \\
\hline Butts, INormen W. & Frye, George D. \\
\hline Butts, William D. & Fulk, Cherles $\mathrm{R}$. \\
\hline Byra, Samuel S. & Furley, Roy \\
\hline Carter, Donald M. & Gage, Bmanuel \\
\hline Castleman, Harold I. & Gadbots, Henry D. \\
\hline Catlett, Curtis & Gainfort, Paul \\
\hline Clccone, Carmen $P$. & Galloska, George Jr. \\
\hline Cloud, Howard I. & Gent, George \\
\hline Cogle, Clarence & Govdnicht, Roy \\
\hline Cole, George E. & Gore, Stewart \\
\hline Crim, Bruce $M$ & Green, Robert \\
\hline
\end{tabular}


PURPLE HEART

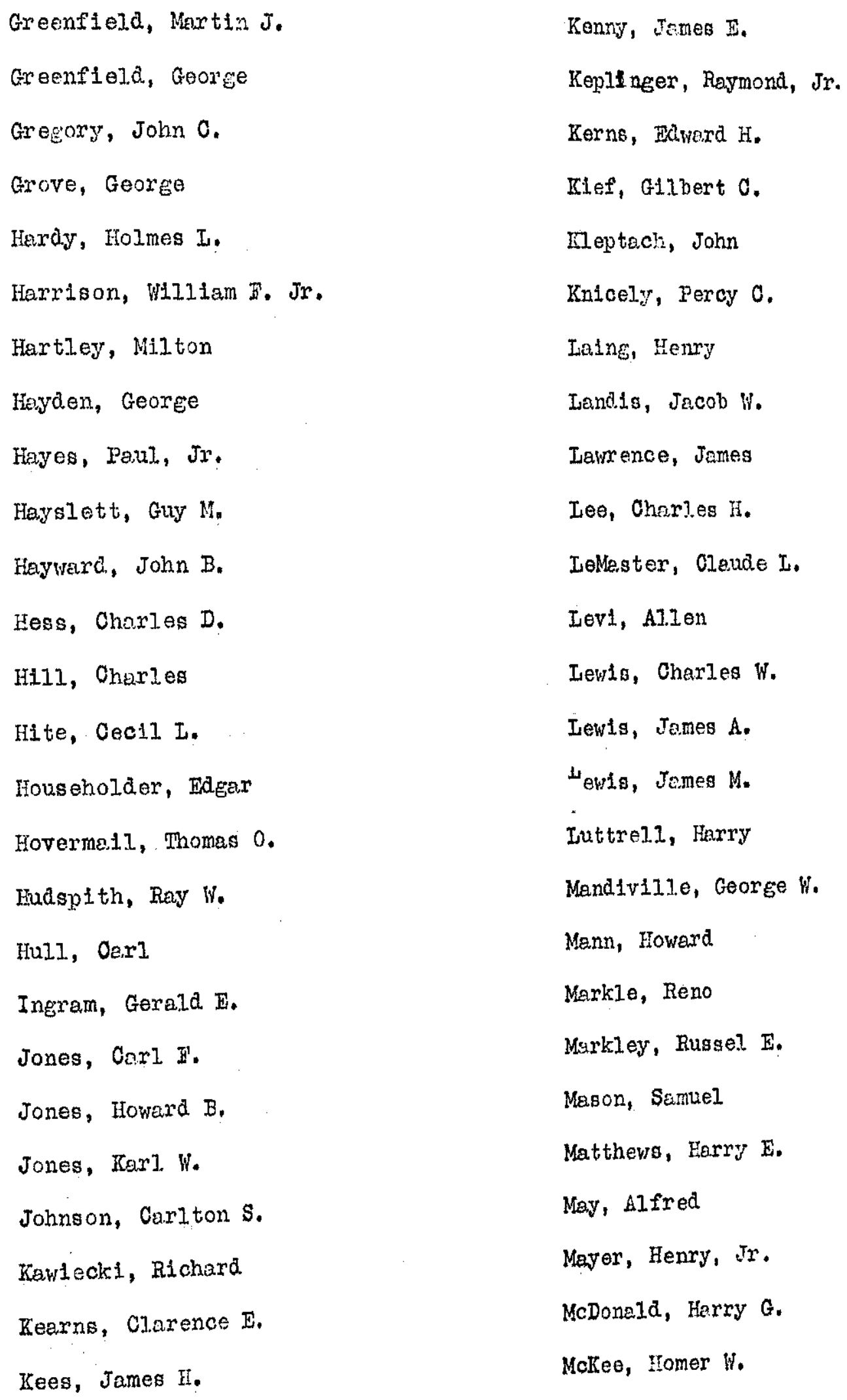


PURPLE HEAPM

\begin{tabular}{|c|c|}
\hline Melburn, Bruce & Robertson, Jullus $P$. \\
\hline Milier, Arthur H. & Rockwell, Chorles A. \\
\hline Miller, Richard c. & Rockvell, Joseph T. \\
\hline Mongan, Bruce & Rovland, Raymond $\mathrm{M}$. \\
\hline Moore, Robert If. & Shick, Maurice I. \\
\hline Morgan, Benjamin J. & Sencindiver, Alfied I. \\
\hline Murphy, Georce 0. & Sencindiver, John $\forall$. \\
\hline Murphy, Kenneth & Sencinaiver, Robert A. \\
\hline Myers, Hurry I. & Sensel, Roy H. \\
\hline Michols, William I. & Shedo, Gilbert I. \\
\hline Nicewarner, Henry $c$. & Sheely, Jomes A. \\
\hline Of Deln, Arthur $\mathrm{H}$. & Sheppord, Troris I. \\
\hline Orndorff, Burmen $T$. & Shlpe, Jack \\
\hline Pace, Jesse 0. & Sinoles, Gurnett $w_{\text {: }}$ \\
\hline Farkinson, Clifford G. & Suirley, Join \\
\hline Piccolomint, Semuel & Suirley, Lawrence \\
\hline Pittanogle, Dovia H. & Shoemaker, Cherles 0 . \\
\hline Prttonogle, Faul w. & Shuman, Villis A. \\
\hline Elune, Lester $\mathrm{H}$. & Sigler, Curtis E. \\
\hline Froper, fivron A. & Stgler, Hevin 0 . \\
\hline Reineke, Wills A. & Smeltzer, Bruce 0 . \\
\hline Richards, John $N$. & Smeltzer, Jack H. \\
\hline Rickel, Pauj. if. & Smith, Donald \\
\hline Rife, Byron $B$. & Smith, Harry A. \\
\hline Ritter, Crum M. & Smith, Nack L. \\
\hline Roberts, Car1 M. & Snyder, Shermsn $B$. \\
\hline
\end{tabular}


Stefano, Ievis W.

Stewart, Douglas Is.

Stewart, OLIVer

Stilwell, Charles $M$.

Stolipher, gdison $W$.

Sturm, Jack I.

Stutzman, Delbert $D$.

Terry, Iuke $\mathbb{E}$.

Teter, Ernest $R$.

Timmons, William I.

Tinsman, Douglas $\mathrm{H}$.
Turner, Harry I.

Tyson, Paul A.

Voorhess, Doneld. E.

Watson, Waltor B.

Welty, Raymond $\mathrm{E}$.

inite, Curtis

White, Walter F.

Hise, Richard I.

Wolford, Meade K.

Young, Goorge s. 
BRONZZ STAR MEDAJ**

Ashby, Howard $M$. Barron, Franc $C$. Beall, Philip D. Bennett, Paul Byrd, Woodrow $S$. Crim, George B. Custer, William it. Dav16, Cherles i. Davis, Robert D. Dunn, Edward. T., Jx. Eckera, Marlin S. Taulkwel?, Charles $C$. Bogle, Everett $s$. Gaitlier, Wililam D, Goodnight, Roy I. Greene, Robert $\mathrm{F}$. Guesford, Devid H. Hansrote, Albert it. Hardy, Holmes I. Llayden, George $\mathrm{H}$. Hess, Charles D. liess, Frederick $B$. Hooges, Allen T., Jr. Hollis, Boyd R. Householder, Edwerd s. Jones, Howard $B$. Keesecker, Leo s. Keller, DoneId H. Keplinger, Rayrond In, Jr. Enicely, Fercy 0. Ievi, AIl on $M$. Mat thews, Harry $\mathrm{z}$.
MeOuster, Victor ih. McGrinn, James $\mathrm{I}$. Moreen, Eenfomin $J$. Michols, Wiltlam I. No11. Max 0. Piccolomini, Smiuel D. PIne, Willians. Flune, Lester ${ }^{\prime}$. Reiney, Cherles s. Fravel, John W., Jx. Rhodes, Robert $s$. Ficlel, penz $w$. Runlies, Lloyd h. Severs, Eurd it. Silirley, Join ti. Shockey, Inbert $W$. Smeltzer, Jack H. Stapler, James if. Stevart, Robert H., Ji. Stokes, Rormon $G$. Stolipher, Edison W. Timberlake, Kobert $S$. Tyson, Peul A. Wedine, Carroll W. Westeruhaver, George I. Watte, Weilter H. Wolford, Meede $k$. Williamson, Suruel $\mathbf{B}$. Hitoe, Richerd $I$. Hise, Roy E. Wnaham, John $\mathrm{H}$.

SILVER SIAR MEDALS*

Gallaske, Georee $J x$. Gano, Iyston $\mathrm{H}$. Grim, Erederick H. Hess, Charles $\mathrm{D}$. Hovermale, Thomas 0.
Koplinger, Raymond I., Jr. Kilmer, John $H_{\text {. }}$ Nyers, Rodger Loon Rauch, John $\% ., J r$.

* Discharge Records, Berkeley Count Olerk's Offico 


\section{AIR MEDALS*}

Albriglat, Kenneth R. Ashworth, Samuel H. Bush, Wallace A. Chambers, Jack H. Cline, Oharles $\mathrm{s}$. Olohan, Arch E., Jr. Collis, Paul P.

DeHaven, Talbert A. Dern, Ernest it. Dever's, Harry Hick, Glarence $W$. Gallagher, Joseph $M$. Hol11s, Trammell. H. Jackson, Eidward $\mathrm{B}$. Jones, Glibert $R$. LaCount, Joseph $\mathrm{s}$. Iewis, James $M$. Iivers, Georee $M$. Long, Clarence W. McKee, Douglas P. Moss, Carroll II. Myers, Roger Leon No11, Bred. A. Pitzer, George D. Psallaas, Andrew Roach, Claude Thomas Taylor, Rawlel.gh $\%$. Terry, Luke $\mathbb{E}$. Wintermoyer, Chester

Cline, Charles s. Defirven, Telbert A. Devers, Hiary Hul1, Carl if. Livers, George M. McKee, Douglas P. Terry, Iuke E.

MAVY OROSS

Frank 0. Thomas, Jr.

* Discharge Records, Berkeley County Clerk's Office, supplemented by Martinsburg News files. 
LIST OF DOCTORS IN SERVICE* BTEREDA EYY COUNTY

Name

Armentrout, A, W. Clapham, Roger E. rialtom, William I. X11mer, John H. Wallace, Williem A. Zepp, E. Andrey Porterfield, Mervin H. Thurston, Harold $B$.
Grade

It. Col.

Itt. Commarr.

Col.

Maj.

Maj.

Iieut.

Oapt.

Iieut.
Branch of Service

Army

Navy

Army

Army

Army

Army

Navy

ITavy

* Martinsburg News files. 
SBLECTIVT SERVICD STATISTIOAL REPORT*

March 15, 1947

Olassificetion

1-0 (a.1. ages) Inducted and enlisted . ...........

2-c offlcers releesed. from

1-0 Enlisted regulax service since September 1, 1945 .

1-0 inlis ted reserve ariny and navy .......

1-0 Discharged : . . . :

1-C Deceased . . . . . . .

$1-G . . . . . . .$.

4-F Discherge .......

3-A Fathers under 30 years old

4-D Ministers ........

4-F Under 30 years oid .... under 30 years. . . .

2-A Merchant marines and industrial deferments under 30

Deceased, all ages, not in service .......

Cancelled, all ages, not $i x_{n}$ service........

1-a over 18 years old . . .

1-A Uider 18 yearg old. ...

Unclessified, 18 years olá, under 19 years. . . .

Totals, less fourth

registration active duty ......

4-A 30 years or older. ....

2-c Farmers on deferment,

Total

White Negro

\begin{tabular}{|c|c|c|}
\hline 156 & 150 & 6 \\
\hline 101 & 101 & $c$ \\
\hline 122 & 125 & $?$ \\
\hline $\begin{array}{r}140 \\
2,446\end{array}$ & $\begin{array}{r}129 \\
2,328\end{array}$ & $\begin{array}{r}11 \\
118\end{array}$ \\
\hline 73 & 71 & 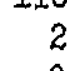 \\
\hline 30 & 30 & 0 \\
\hline 201 & 1.99 & 2 \\
\hline 3,396 & 3,148 & 148 \\
\hline 18 & 17 & 1 \\
\hline 620 & 583 & 37 \\
\hline 33 & 33 & 0 \\
\hline 4 & 4 & 0 \\
\hline 54 & 49 & 5 \\
\hline $\begin{array}{l}29 \\
46\end{array}$ & $\begin{array}{l}25 \\
43\end{array}$ & 4 \\
\hline 12 & 12 & 0 \\
\hline 136 & 127 & 9 \\
\hline & 17 & \\
\hline
\end{tabular}

Non-registrants Irom Berkeley County

Non-resistrants still in service. . 265

" $"$ " discharged. .... 79

deceased, on duty. . 10

offlcers, relersed

frou uctive duty...... 18

Total : $\overline{372}$

* History, Iocel Boara, Selective Service, Mertingbure, Berkelex County, West Virginia, by E. M. S1tes, Clerk. 
SELEOITIV SHRICE BOARD PERSOMIAT

October, 1940 , to July, 1941

B. D. Nyers, Chairnan

Paul H. Martin, Secretary

James I. Dilion

Albert Schneider, CJ.erk

Miss Lela Gain, Stenographer to November 12, 1940

JuIJ, 1941, to Hovember, 1942

G. O. Mckown, Chairman

E. W. Rhodes, Secretary

W. N. MicBride

Paul H. Martin, Clerk.

Miss Edna I. Luttrell, Assistant Clerk from November 12, 1940

November, 1942, to Morch, 1947

G. C. MoKown, Chasrman

i. W. Rhodes, Secretary

W. N. MoBrlde

Hagar M. Sites, Olerk

Miss Edna I. Iuttrell, Assistant Glerk

Goverument Appeal Agent

Lacy I. Rice

Examining Plysicians

Dr. George 0. Martin, Chairman

Dr. A. H. Armentrout

Dr. Ernest H. Bitner

Dr. Roger E. Olapham

Dr. A. Bruce Baglo

Dr. J. K. Guthrie

Dr. William I. Haltom

Dr. iN. B. Hendrix

Dr. G. P. Morrison

Dr. Max 0. Oates

Dr. T. K. Oates

Dr. Marvin H. Porterfield

Dr. C. G. Power

Dr. R. B. Talbott

Dr. William A. Wallace

Dr. H. R. Dufruy

Dr. John Hodges

Examining Dentists

Dr. W. H. Flanagan

Dr. J. G. Kearfott, Jr.

Dr. W. E. Minghini

Dr. H. Scott Gardiner 
SELICTIVE SHRVICE PIESONNEL, CONPID.

Advisory Board for Registrants

Judge D. H. Rodgers, Ohairmen

Atty. Herbert I. Hannis

Atty. Charles R. Beall

Atty. R. H. Boyd

Atty. Hugh s. Byrer

Atty. Wilting C. Foulkner

Atty. Oharles G. Gain

Atty. I. I. IuttrelI

Atty. Clarence E. Martin, Jr. Atty. Lacy I. RIce

Atty. R. Jacob Schleuss

Atty. Carroll. T. Sencindiver

Atty. Gray Silver, Jr.

Atty. A. Hamilton Shipper

Atty, Harry A. Downs

Clerical Workers

Miss Dorothy Shlrley, Part Timo

Mrs. Lucille Short, Part Time

Mrs. Oatherine Vatson, Part Time

Miss He1lie S. Cushwa, Stenographer

Mr. Henry I. Riker, Office Olerk

Mr. Fdwin R. Kilmer, Office Olerk

Miss Dora Ann Spinett1, Stenographer 


\section{CIVIJIAN DEFENSE PARSONADL, * \\ BERKFHISY COUNTY \\ $1942-1945$}

Administrative

Chairman

Tidgar $\mathrm{H}$. Berry to January 12,1942

C. Joseph Crebill from Ianuary 21, 1942

Coordinator

Bdgar H. Berry to January 12, 1942

J. Howard Nyers from January 21, 1942

Auxiliaxy Police Committee

Eager M. Rlorkan, Chm. Comnander Berkel ay Post No. 14, Amertcan Legion

Utility Oommittee

Marvin Hawk, Chm. Manager, Potomac-Bdison Oo.

Air Rald Warning Service

G. William Ropp, Cochm. to June, 1942

A. R. Inmert, Co-

Superintendent, Berkeley County Schools

chm. to June, 1942

Busiuess leader

o. J. Mortin, Ohm.

after June, 1942

Zone Vardens, Martinsbure

Chester J. Martin

George No Drien

Martin I. Depenbrock

D. Floyd Evans

Carlton I. Stucky

Carl I. Wellinger

Noble D. Ridings

First Ward

Second Hard

Tiuird Ward

Fourth Ward

Nifth Nard

Sixth Ward

Seventh Werd

Zone Wardens, County**

Edwin W. Miller

Arden District

A. G. Sanders

Faline Waters District

Cax1 W. Wiest

C. J. Cunningham

Paul W. Ridgeway

T. J. McCarthy

Gerrardstown District

Hedgesvilie District

Mill Creek District

Opequeon Distrlot

* From the files of the Martinsbure Hews.

* The Martinsburg Journal, December 17, 1941 


\section{Finance Committee}

Tremmell Hollis, Ohm, Bustness leader

Thrift and Conservation Board

Marlin S. Hckard.

Postmaster

\section{Communications Service}

C. J. Crabill, Chm. Herry I. Reeves

Manager, Martinsburg Gas Oo. Manager, C. \& $R$ Telephone Co.

\section{Medicel Service}

Dr. IN. B. Hendrix, Chm.

Dr, II. R. Dupuy

Dr. Max Oates

Pres., E. Pahhandie Med. Asan.

Berkeley Co. Health officer

Dr. William I. Haltom

Red Cross Medical Adviser and Pres., Clty Hospltal Staff

Fres., Kings Daughters Iosp1 tal Staff

\section{Nursing Service}

Virs. Owen Velsh, Ohm.

Mss Mergeret Shoup

Suplt. of Iruses, City Iospltal

Miss Muble Fuller

Sup't of Ifurses, IK. D. Hlospital

Provision for emergency service by members of the State Nurses Association, County Health Department nurses and local murses aldes.

\section{Messencer Service}

Nrs. Frank 0. Thomas, Co-chm.

Burkhert Irauge, Co- Maneger, Western Union Telegraph 0 .

chm.

GIrI Scout Counc1l.

\section{Road Repair Crews, Demolition Clearance Corps,} Decontamination Corps, Bomb and Rescue Squads

P. G. Petri, Chm. Charles Wever Tull Whitacre Devia Thompson
$B$ \& O Railroad

City Engine er, Martinsburg

Stato Roed Comnission offlce

City street Sup't., Martingburg 
Publicity Director

King Larkin

Donald Rentch

Neuspeper man

Personnel officer

John D. Martin

Comnender

Harry C. Harnmenn

Agriculture

iv. N. KoClung, Chm.

County Asent

James I. Dillon

USDA Defense Board Chm.

CD Treining Classes

Paul W. Swope, Ohm.

\section{Ration Board}

J. Roy Nadembousch, Chm. Business Leader FAvin Miller

Hoger I. Henshay

Principal, Martinshurg High School

\section{Salvage Ofmmittee}

Iou Cohen, Chm.

War Finnce Oommittee

R. Lewis Bentr, Generel Chm.

Bernara D. Myers

$J$. Howerd Nyers

Ohm. Panking Division

HIbur Il. Thomas

Chm. Industrial Payroll Division

Mrs. H. G. Ma1se], Sr.

Buxton Kertin

Chm. Community Division

Chm. Women's Division

Publicity Cholrman 
USO Executive Committee

O. Granville Smith, Chm. Mrs. H. F. Thorn

J. R. Nadenbousch

Mrs. R. G. Coffman

Col. Bverett I. Cook

Meti. T. M. Arnett

RED CROSS FERSONEEL *

Chapter officers

Chairman

Vice-Ohairnen

Secretary

Treasurer

Urs, Russoli J. Bergen

ifrs. Howerd $\mathrm{K}$. Brown

HAas Mol? el. Te Kuykendall.

Herbert A. Avey

Services and Corps Chairman

Home Nurging

Diasster

Home Service

Nutrition and Canteen

Hirst Ald and Accident

Junior Red Cross

Arts and Crafts

Blood Donors

Camp and Council

Mrs. Felix Schnelderhan

Grey Ladies

Iife Saving

Motor Corps

J. Roy Nadenbousch

Geore hintmore

Mrs. Edger M. Sites

Julian 0. Hidwiler

Mrs. John Redue

Mrs. Laud Byers

Mrs. H. I. Reaves

John Ruprecht and Mrs.

H. S. Whitacre

Mrs. James A. Trump

Miss Jean Durbor ow

Mrs. Siduey Lowery

Irurses Aides

Mrs. Paul A. Bennet t

Production

Mrs. H. S. Gardner, succeeded

Publicity

Recruiting Nurses

Staff Assistance

by Mrs. Edwin Miller

Mrs. M. A. Snodgrass, succeeded by Miss Ruth Darby

Miss Eleanor Miller

Mrs. Hoover I. Iloyd

* Martingburs Nows Files. 
Red Oross War Fund Chairman

Spring, 1942

Spring, 1943

Fal1, 1943

Spring, 1944

Be11. 1944

Spring, 1945
R. I. Bentz Meryman Gilbert Garland Dunn John I. Iightnex Clarence E. Martin, Jx., Co-chn . Join I. Jadenbousch, Co-Chm.

STATE SURVEY OE AVAIJABIE SOFOOI FACIJITIES TOR HAR BMERGDINCY*

Berkeley County Report

March 28, 1942

No. of schools which would be used for

housing evacuees or troops............ 8

No. of persons per day for whom food could

be prepared with present faclitities ......... 945

Cots and beds available in the schools and

estimated no. available from other agencies ....... 139

iNo, of cots which space will accommodate . . . . . .1450

Wo, of showers ................... 26

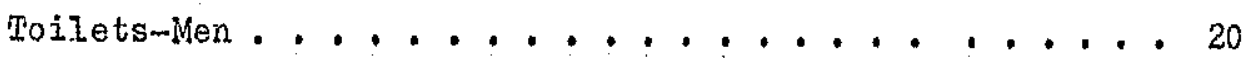

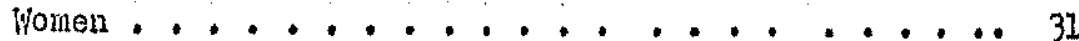

First Aid in schools. ..............4 4

Telephones in schools.............. 8

* OCD General Correspondence No. 2, War History Commission

Records, Hest Virginia University Iibrary, Morgentown. 
WAR LOATT DRIVES

Statistica for Berkeley County

War Loan

First Lrovember 30-December 31, 1942

Second April 12-May 1, 1943

Third September 9-0otober 2, 1943

Fourth January 18-February 15, 1944

Fifth June 12-July 8, 1944

Sixth Novern er 20-December 16, 1944

Seventh May 14-June 30, 1945

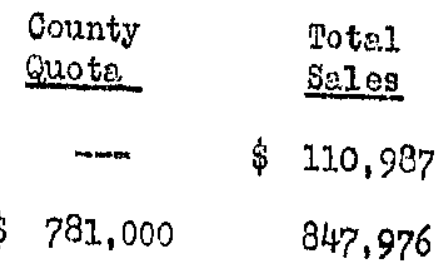

$$
\begin{array}{rr}
1,439,900 & 950,584 \\
686,200 & 906,258 \\
820,000 & 1,023,215 \\
674,000 & 1,125,237 \\
296,000 & -1,724,242 \\
\hline \$ 5,508,000 & \$ 6,688,399
\end{array}
$$

Recoras of the State Director, Ireosury Dopartment, U. S. Saving's Bonds Division, Charleston. 
APPIXIXIX III

MAF OF BURXYLEY COUNIY 


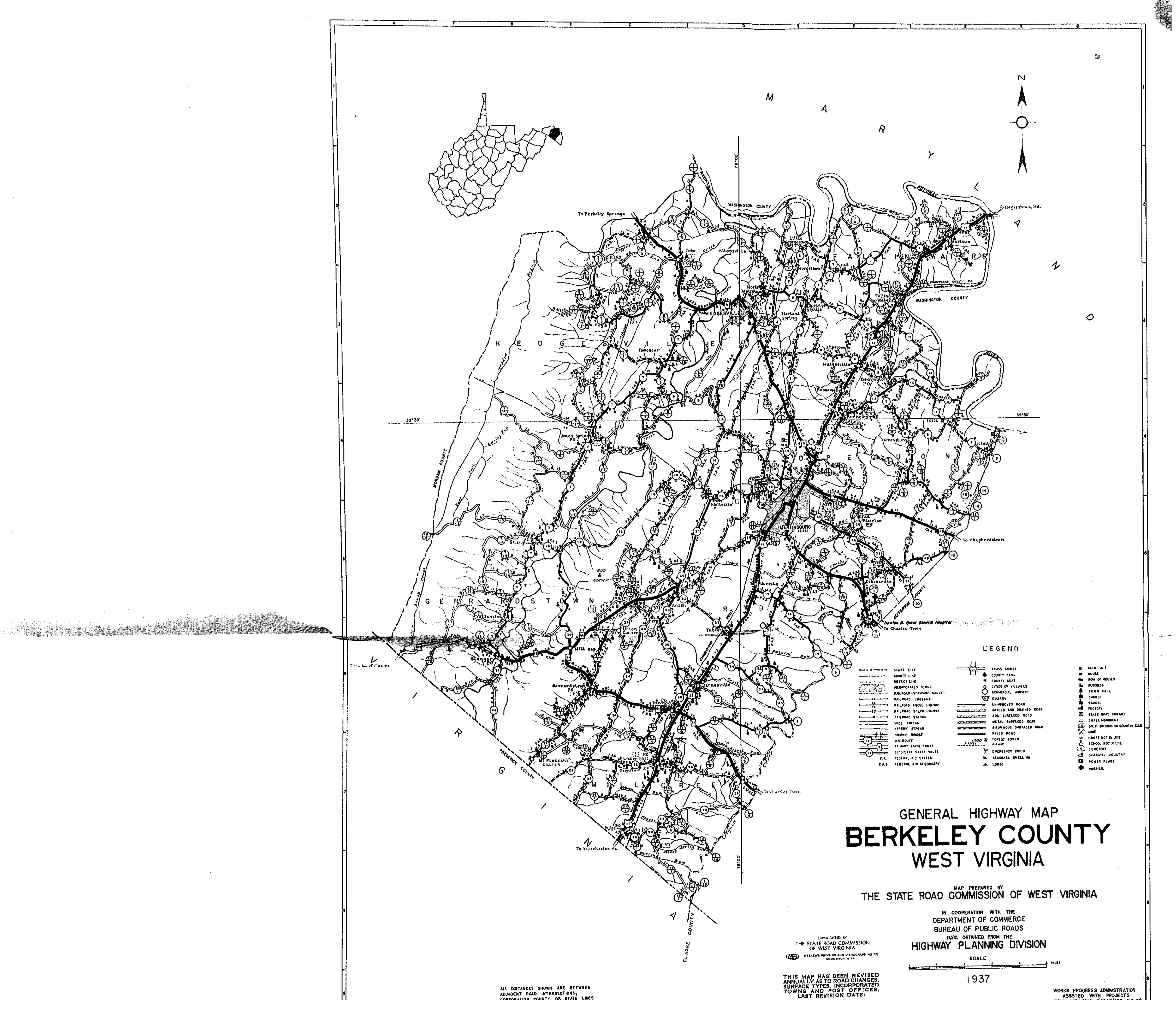


BIBLIOGRAIEY 
BI TIIOGRAPHY

Alj. sources listed are Primery except the first two under V Miscellaneous.

I Pexsonal Intervievs:

The following people were personelly intenviewed;

Armbrester, Peul Vernon, Vocational-Agriculture Teacher, Hedgesville High School.

Beall, Charles R., Boy Scout Cormissioner, MartinsburE.

Berg̈en, Mrs. Russell J., Chairmen, Berkeley County Chapter, Red CxOBs, Martinsbure.

Benta, R. Lewis, Chairman of Civilian Defense War Hinance Comnittee, Martinsburg.

Brand, Robert C., President of Brand Engineering Company, Martinsbur.̈.

Byser, Harry H., I \& 0 Counsel, Martinobure:

Byrer, John G., Editor of Martingburs Neys.

Byrer, Join G. (Hirs.), Hiece of Commodore I. E. Vonletre, Martinsburg.

Olapham, Frankiln, Fermer, former ormer of ilowton D. Baker Hospitol site.

Olerke, Melson, Enecutive Secretary, Mertinsbure Chember of Commerce.

Cook, Colonel Ernest I., Commanding Officer of Newton D. Baker Hospital.

Orowe11, Jack, Nanager of Rent Control Office, Martingburg;

Dunn, Garland I., Vice-President of Dunn Woolen Company, Martinsburg.

Hammersla, C. Lee, Manager of Nertinsburg Branch, National Sruit Products Company.

lienshaw, Edgur I., Ration Board Member, Martingbure,

Mc01ang, W. IN., Oounty Agent, Martinsbure.

MoKown, Gilbert $0 .$, Editor of the Mitinsburc Jouran.

Moyer, Wulter, Generel Manaser of C. K. Lusgelmen and Compau, Inwood. 
Poland, John R., President of Perfection Garment Company, Mertinsburg.

Porter, Mrs. Harry, Girl Scont Commissioner, Mertinsburg.

Reaves, Mrs. Herry I., Cheirman of Red Cross Blood Dontng Service, Mertinsbur:

Reynolds, T. Gug, First Lientenent, Civil Air P atrol, Martionsburg.

Ropp, G. Wlilism, County Superintendent of Schools, Martinoburs.

Sites, Edgar M., Commanding Officer, Stete Guard, Compeny D; Clerk, Selective Service Boerd, Martinsburg.

Smith, O. Granvilie, Clvilian Defense Recreation Cholman, Mrtinsburg.

Taylor, Bennett, Personnel Manager, Interwoven Stocking Company, Martingbure.

Tonry, J. G., B \& O Yardmaster, liertinsbiurg.

Willians, R. C., Meneger of Berkeley Woolen Compony, Martinsburs.

Hood, Ceci]. W., Oxchardist, member of Hest Vireinia Horticui ture Soclety and State Guard Compeny D, iledgesville.

Youne, George S., Veteren of World Har II, Hedgesville.

II Newspepers

Baker's Better, 1944-1946. War Ilistory Commisaton Records, West Virginia University Library, Moreantown; Martingburg: News, $1941-1945$.

The Martinsburg Journal, June 20, 1940; December, 1941, to February, 1942; and Februiny 19, $195 \%$.

II Mgazines

Mountaineed Defense, 1942-1944. War History Commss1on Records, West Virginia University Iibrary, Morinton.

The West Virginta zeviou, My, 1044 .

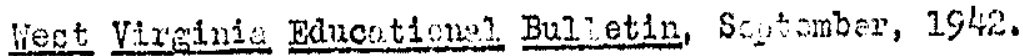


IV Official Records, Ryorts and Publications

Armuel Darrative Report of the County Agent, Berkeley County, West Virinie Asricultura. Extension Service, Morgontown, $1947-194.5$.

Discherne Records, Berkel ey Count CIerk's Office, Mertinsburg:

OPliciol Fecords of the West Vircinia Selective Service hea quarters, Charlestoj.

Offician Records of the West Virginia orfice, U. S. Trensury Department, Sevings Bond Division, Cherleston.

U. S. Census of Aricuj, ture, Virgints gnd West Virginia, 1945; Departnent of Comnerce, Washington, D. 0 .

West Virginia Blue Book, Jarrett Printine Company, Churleston, Forla War II Honor List of Dend anä Hissing, State of Vest Virginia by Counties, War Degartment, Charleston.

$\checkmark$ Miscellaneous

I Alexander, Herbert I., A Short Listory of the Late Honorable Newton D. Beker, Martinsburg Chamber of Comrnerce pamiklet,1943.

2 Brano, Robert C., Ilmestone Production in West Virginia, Printed copy of a speech presented to American Institute of Mining end Metallurgical Engineers, Morgantown, September, 1951.

3 Emoloyment Survex, Martinsbure and Berkeley County, 19411947. Mer'tinsbure Charaber of Commerce.

4 Historical Annual, Nationel Guard of the State of West Virglnia, Arny and lavy Publishing Corpony, Beton hovee, Ioustana, 1938.

5 Sites, 패gar K., History, LoceI Board, Selective Service, Martinsburg, Berkeley County, West Vireinia, Mirch, 1947 . Us.

6 War History Commission Records, West Virminie University Iibrury, Mor Eantown. 


\section{AESTRACI}

In this study of Borikeley County in Worjd war II an attempt is mede to sunnarize the county's contribution to the war effort and the principal effects of the war upon the county,

From its $30,3.43$ population the foremost contribution was that of the 3518 men and 99 women who entered the federcil service to give of their energies and lives-ma contribution approached. only by tinat of the families from which these men and women came.

The strategic locetion of the county with reference to the netion's capital, the Baltimore and Ohio Railroad, the Potomac River and $U$. S. Route Eleven, designated by the War Department as the second line of defense of the eastern seaboard, brought a real sense of the nearness of war to those remaining on the horae front. Civilian defense was orgenfzed and meinteined with enthusiosm, its efforts centering at first around aif radd protection, and in later months in the bond and stamp carpeigns with which to help finance the war. The Berkeley County Ohpter of the Red Cross expanded its progrem and worked unceasingly; its projects were nany and varted. The school. system revised its curricula to met the needs of those students interested in aeroneutics and others prepering to answer

the urgent cells for office vorkers in Washington. A defense trainIng school set up in Martinsburg trained many hundreds of students for specialized jobs in the aircrast plents of Faltimore and Haserstown, Herylond. The lixee commity canning conters instituted by the board of education proved invaluable assets to the communties of Hedgesvi11e, Wrtinsbur and Buncei lil1. To furtier protect the home front, State Guard Company D was activeted and received training throughout the war period in preparetion for en emergenco arisinf from inverion or civil disturbance. 
Although not esentially industrifl, Berkeley County prom duced limastone from its quarries for use ln the manufacture of ateel and contributed various textiles and frut products to the armed forces. Another of Its largest employers, the Baltimore and Ohto ${ }^{K}$ aflroad, plifyed a vitel port in the wer effort. Farming, long the chief occupation of the county, was perhaps the most arasticelly affected br the wer. In spite of the hardsips in the form of lebor and materiel shortages which it inflicted, the war lifted farming out of the aepths of the depression which had held it since 1930 and made it an industry in its ow right.

Finaliy, this study deels with the foundine and operetion by the army of Nevton D. Bekex Hospital, which was, next to tine areft, the nost fermeaching war activity to take place in Berkeley County. 


\section{BIOGRAIIY}

Patricle W. AJger was born Patricio. Anil Hood in Martinsbur Berkeley County, on Novenber 4, 1924. She attended Iredgesville Flementery and Figh Schools, graduoting from the latter in 1941. From 1941 to 1943 she was a student e.t Shepherã College, Shepherdstown, from which she transferred to Hood Collece, Prederick, Wayland. She wes greduated from this institution in 1945 with an A. B. demree in history. During the school yeer 1945-1946, she was employed by the Jefferson County Boord of Eâuation as a teacher of social studies and English in Hexpers F'erry High School. Sho resigned this position to attend the sumer sessions at West Virginia University and remained Ir Morgentown until June, 1948, continuing her greduate studies, with the exception of the summer and fell terms of 1947. She accepted a positiou as history and social studies teacher in Hedgesville Higin School In 1948, and since the close of that school yesr has not been publlcly enmloyed. Her marriage to Sylveston. AIger, Jr., of Hedgesville, occurned May 25, 1946. The foulity now includes three clilidren: Robert Dana, born Novemb:r 4, 1947; W117iam Foster, October 20, 1949; and N1isabotis Anu, Mely 5, 1951. 


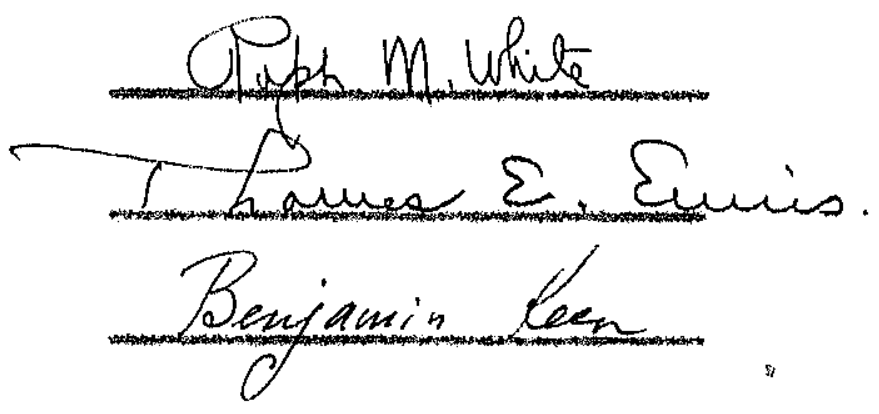

$\frac{d h+161 J^{2} z}{0.67}$

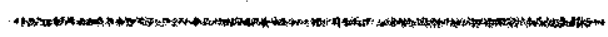

Pfitianmanes

(6) $2 x+5$ 